\title{
Çocukların Dijital Oyun Bağımlılığına Göre Aile Profillerinin Belirlenmesi*
}

\section{Emrullah YİĞİT**, Selim GÜNÜÇ***}

Öz: Bu çalışmada çocukların dijital oyun bağımlılığına göre aile profillerinin belirlenmesi amaçlanmıştır. Bu nedenle ilk olarak çocuklara dijital oyun bağımlılığı ölçeği uygulanmış ve çocukların dijital oyun bağımlılığı düzeyleri belirlenmiştir. Ayrıca dijital oyun bağımlılığı ölçeği sonucuna göre; oyun bağımlılık puanları en yüksek olan çocukların ebeveynleri ile oyun bağımlılık puanları en düşük olan çocukların ebeveynlerinden yarı yapılandırılmış görüşme yoluyla nitel veriler toplanmıştır. Çalışmanın örneklemini; 2015-2016 EğitimÖğretim yılı bahar döneminde Van ili Merkez ilçesinde bulunan özel bir kolejin ortaokulunda (5., 6., 7. ve 8. sınıflar) eğitim gören çocuklar ile bu çocukların ebeveynleri oluşturmuştur. Çalışmada karma yöntem kullanılmıştır. Çocukların dijital oyun bağımlılığı düzeylerini betimlemeye yönelik toplanan veriler çalışmanın nicel boyutunu; çocukları dijital oyun bağımlısı olan ebeveynler ile çocukları dijital oyun bağımlısı olmayan ebeveynlerle yapılan görüşmeler ise çalışmanın nitel boyutunu oluşturmuştur. Nicel verilerin analizinde betimsel istatistikler, iki aşamalı kümeleme analizi ve doğrulayıcı faktör analizi kullanılmış, nitel verilerin analizinde ise içerik analizi kullanılarak alt tema ve ana temalar oluşturulmuştur. Bulgular doğrultusunda iki grup karşılaştırılmıştır. Çocukların dijital oyun bağımlısı olup olmamasında ailenin kalabalık yapısı, aile içerisindeki kural ve sınırlar, anne veya babanın çocukla ilgilenme durumu, ailece yapılan sosyal etkinlikler, teknoloji ve zararlarına ilişkin farkındalık gibi bazı faktörlere ulaşılmıştır.

Anahtar Kelimeler: dijital oyun, oyun bağımlılı̆̆ı, aile profili, aile yapısı, aile içi iletişim.

\section{Determination Of Children's Family Profiles According To Their Digital Game}

\section{Addiction}

* Bu çalışma Yüzüncü Y1l Üniversitesinde yapılan yüksek lisans tez çalışmasından türetilmiştir.

** Öğr. Gör., Hakkari Üniversitesi, Bilgisayar Teknolojileri Bölümü, Eposta:eyigit87@gmail.com, Orcid No: 0000-0002- 5319-0798

*** Doç. Dr., İzmir Bakırçay Üniversitesi, Psikoloji Bölümü, Eposta: selim.gunuc@bakircay.edu.tr, Orcid No:0000-0002- 2278-7882

Gönderim:14.10.2019

Kabul:26.12.2019

Yayın: 29.02.2020 
Abstract: In this study, it is aimed to determine family profiles of children based on their digital game addiction. Firstly, digital gaming addiction scale was applied to children and digital game addiction levels of children were determined. Then, Qualitative data were gathered through semi-structured interviews with the parents of the children who have the highest and the lowest gaming addiction scores at digital game addiction scale. The sample of the study consisted of the children who were attending in the secondary school (5th, 6th, 7th and 8th grades) of a private college in the central district of Van province in the second term of 2015-2016 academic year and the parents of these children. Mixed method was used in the study. The data collected to describe the levels of digital game addiction of children constitute the quantitative dimension of the research; on the other hand, interviews with parents whose children are addicted to digital games and parents with children who are not addicted to digital games constitute the qualitative dimension of the research. In the analysis of quantitative data, descriptive statistics, two-step cluster, confirmatory factor analysis were used, and in the analysis of qualitative data, sub-themes and main themes were formed by using content analysis. The two groups were compared according to the findings. Some factors such as the crowded structure of the family, rules, and limits in the family, the status of caring for the child, social activities carried out by the family, and the awareness of the technology and harms have been found to be the determinants of whether children are addicted to digital games.

KeyWords: Digital game, game addiction, family profile, family structure, family communication.

\section{Giriș}

İçinde bulunduğumuz teknoloji çağında internet, her yaş grubu tarafindan yaygın olarak kullanılmakta ve bu amaçla bilgisayar, tablet, akıllı telefon gibi cihazlar sıklıkla tercih edilmektedir. Teknoloji her yaş grubuna hitap ettiği gibi çocuk ve ergenlerin de sürekli ilgisini çeken ortamlardan biri olmuştur. Türkiye İstatistik Kurumu'nun (TÜİK) 2013'te yayınladığı 06-15 Yaş Grubu Çocuklarda Bilişim Teknolojileri Kullanımı ve Medya araştırmasının sonuçlarına göre; Türkiye'deki 06-10 yaş grubundaki çocukların bilgisayarları kullanma yaşı ortalaması 6, 11-15 yaş grubundakilerin ise bilgisayarları kullanma yaşı ortalaması 10 olarak tespit edilmiştir. Aynı araştırmada 06-15 yaş grubundaki çocukların \%24'ünün kendilerine ait bilgisayara sahip olduğu, \%13'ünün cep telefonuna ve \%2'sinin de oyun konsoluna sahip olduğu ifade edilmiştir (TÜİK, 2013). Her geçen gün gelişen bilişim teknolojileri ile insanların bilgiyi edinme şekilleri, iletişim, alışveriş ve eğlence anlayışlarında 
bazı değişimler meydana gelmiş, teknolojilerin yanlış veya hatalı kullanılmasından doğan bazı problemler ortaya çıkmıştır. Bu değişim ile birlikte yeni kavramlar da tanımlanmıştır. "Bilgisayar bağımlılı̆ğ”, “internet bağımlığı” ve “oyun bağımlılı̆̆ı” gibi kavramlar bu duruma örnek olarak gösterilebilir. Oyun bağımlılı̆̆ı, bilgisayar ve video oyunlarının sosyal veya duygusal sorunlar ortaya çıkaran aşırı ve problemli kullanımı olarak tanımlanmaktadır (Lemmens, Valkenburg ve Peter, 2009). Bağımlılar teknolojik cihazlarla daha fazla zaman geçirmek için uykularını, beslenmelerini, alışkanlıklarını ve sosyal yaşamlarını ihmal etmektedirler (Young, 2009). Bağımlılık gizli olan bir süreçten geçer ve genellikle birey, bir bağımlı olduğunun farkına varmaz ya da bu durumu çok geç fark eder (Günüç, 2009).

İnternette bağımlılık yapan aktivitelerin en önemlilerinden biri dijital oyunlardır ve internete bağımlı olan bireylerin interneti en fazla tercih etme sebeplerinin başında oyun oynama davranışı gelmektedir (Günüç, 2009). İnternet bağımlılığı ile dijital oyun bağımlılığı çoğu zaman birbiri ile paralellikler gösterir (Ng ve Wiemer-Hastings, 2005; Günüç, 2015). $\mathrm{Bu}$ anlamda, davranışsal bağımlılıklar kategorisinde bulunan internet bağımlılığı ve dijital oyun bağımlılığı arasında güçlü bir ilişki bulunmaktadır (Günüç, 2015). Alanyazında internet bağımlılığı ile dijital oyun bağımlılığının belirtileri ve olumsuz etkilerinin de benzer olduğu ifade edilmektedir (Kim, Jeong ve Zhong, 2010). Amerikan Psikiyatri Birliği (APA) tarafından geliştirilen ve Mayıs 2013'te yayımlanan Ruhsal Bozuklukların Tanısal ve İstatistiksel El Kitab1-5'in (DSM-5) üçüncü araştırma ekinde dijital oyun bağımlılığı, internette oyun oynama bozukluğu (Internet gaming disorder) olarak yer almıştır. İnternette oyun oynama bozukluğu normal aktivitelerin bozulma oranına bağlı olarak hafif, orta ya da şiddetli olabilmektedir. İnternette şiddetli oyun oynama bozukluğu olan bireylerin diğer insanlarla olan iletişimleri, iş veya akademik yaşamlarının daha fazla zarar göreceği ifade edilmiştir (American Psychiatric Association, 2013).

Çocukları tehdit eden dijital oyun bağımlılı̆̆ı, onların gelişimine zarar verebilmektedir. Dijital oyunlar çocuklar için; oyunlarla çok fazla zaman harcama, derslerini aksatma, kendilerini oyun karakterleri ile ilişkilendirme, oyun oynarken müdahale edildiğinde aşırı tepkiler verme gibi biyo-psiko-sosyal riskler barındırmaktadır (Taylan, Kara ve Durğun, 2017). Küçük yaşta dijital oyunlarla karşılaşmak veya ilk teknolojik cihazlarına erken yaşta sahip olmak, dijital oyun bağımlılı̆̆ı riskini arttırabilmektedir (Bülbül, Tunç ve Aydil, 2018).

Aile toplumun yapı taşıdır. Çocuk, ilk iletişim deneyimlerini aileyle yaşar ve böylece sosyalleşme sürecinin ilk adımı başlar. Aile üyelerinin karakterleri, davranış ve tutumları, 
hayat hakkındaki görüşleri çocukların gelişim sürecini etkileyebilmektedir (Kırık, 2014). Fiziksel ve zihinsel olarak gelişimlerinin önemli bir evresinde olan çocukların oyun alışkanlıklarının bilinmesi önemlidir. Bu noktada ebeveynlere önemli sorumluluklar düşmektedir. Anne ve babanın ilgi ve eğilimleri, duygusal tutumları çocukları dolaylı veya doğrudan etkilemektedir (Akkoyunlu ve Tuğrul, 2002). Ebeveynlerin eğitim düzeyi, teknoloji ile olan ilişkileri, çocuklarıyla olan iletişimleri, maddi olanakları gibi faktörler çocuklarının dijital oyunlara yönelmesinde etkili olabilmektedir. Bu bağlamda bazı çalışmalarda anne ve babanın eğitim düzeyinin arttıkça çocuklarda oyun bağımlılığı düzeyinin de arttığı sonucuna ulaşılmıştır (Gökçearslan ve Durakoğlu, 2014).

Ailesiyle sağlıklı bir ilişki geliştiremeyen bireyler daha fazla dijital oyun bağımlılığı riski taşımaktadır (Wang ve Wang, 2013). Kayri, Tanhan ve Tanrıverdi’nin (2014) yaptığı çalışmada; aileleri ile ilişkilerinin iyi olmadığını söyleyen öğrencilerin daha fazla internet bağımlısı olduğu, bu nedenle ailelerinden istenen düzeyde sosyal desteği alamayan öğrencilerin bu eksikliklerini gidermek için internete yöneldikleri ortaya çıkmıştır. Durmuş ve Kaya'nın (2008) çalışmasında ise ebeveynler bilgisayarları oyun oynamak için ne kadar sıklıkla kullanırsa çocukların da bilgisayarları bu amaçla kullanım sıklıklarının arttığı sonucuna ulaşılmıştır. Çalışkan ve Özbay (2015) yaptıkları bir araştırmada, öğrencilerin \%26,3'ünün teknolojiye ulaşma noktasında ailesiyle sorunlar yaşadığı, bu nedenle aile ortamından sıkıldıkları ve uzaklaşmak istedikleri ortaya çıkmış, bu durumun ise bilişim teknolojilerinden dolayı aile içerisinde bir ayrışmanın başladığını gösterdiğini ifade etmişlerdir. Bilgisayar oyunları zamanla, çocuğun aile ve çevresiyle olumsuz ilişkiler geliştirmesine, akademik başarının düşmesine, okul hayatına karşı yabancılık hissi duymasına ya da bağımlı hale gelmesine neden olabilmektedir (Erboy ve Akar-Vural, 2010). Bu nedenle, çocukların internette iken ebeveynlerinin takibinde olması önemlidir (Rosen, Cheever ve Carrier, 2008). Kırık'ın (2014) ebeveynlerle yaptığı çalışma sonuçlarına göre; ebeveynlerin yarısı, çocukları internette zaman geçirirken onları takip etmediklerini ve kendi işleriyle meşgul olduklarını beyan etmişlerdir. Başka bir çalışmada ise, aile kontrolü olmadan dijital oyun oynayan çocukların oyun bağımlılığı düzeylerinin, aile kontrolü altında oynayan çocuklara göre daha fazla olduğu ortaya çıkmıştır (Göldağ, 2018).

Yukarıda da özetlendiği üzere alanyazında dijital oyunlarla ilgili bazı çalışmalara rastlanmıştır. Ancak, özellikle de çocukların dijital oyun bağımlılığında aile yapılarının bir etken olup olmadığının incelendiği veya aile profillerinin detaylı olarak betimlendiği çalışmalara pek rastlanmamıştır. Alanyazında bu kapsamda bir boşluk bulunmaktadır. Bu 
çalışmada, teknolojiye erişim konusunda problem yaşamadığı düşünülen ve devlet okullarına göre daha iyi sosyo-ekonomik olanaklara sahip olan özel bir kolej seçilmiştir. Çocukların dijital oyun bağımlısı olmasında sadece koşulların değil, aile profillerinin de etkisinin belirlenmesi bağımlılığı önleme açısından önemli görülmektedir. Bu nedenle, dijital oyun bağımlısı çocukların aile profilleriyle dijital oyun bağımlısı olmayan çocukların aile profillerinin karşılaştırılarak bazı faktörlerin belirlenmesi önemlidir. Bu çalışmada, temel olarak: Özel kolejde okuyan öğrencilerden dijital oyun bağımlısı olan çocukların aile profilleri ile dijital oyun bağımlısı olmayan çocukların aile profilleri nasıldır? Sorusuna odaklanılmıştır. Bu bağlamda, dijital oyun bağımlısı olan çocuklar ile dijital oyun bağımlısı olmayan çocukların ebeveynlerinin aile yapıları ve çocuklarıyla olan ilişkilerinin incelenmesi amaçlanmıştır.

\section{Yöntem}

Çalışmada temel amaç doğrultusunda 4 alt problem belirlenmiş ve bu problemlere cevap bulmak adına kullanılan yöntemlere ilişkin bilgiler Tablo 1'de özet olarak gösterilmiştir.

Tablo 1.

Alt Problemlere Bağlı Olarak Kullanılan Yöntemler

\begin{tabular}{|c|c|c|c|}
\hline Alt Problemler & Kullanılan Yöntem & Örneklem & Ölçme Aracı \\
\hline $\begin{array}{lcr}\text { 1.Özel } & \text { kolejde } & \text { okuyan } \\
\text { çocukların } & \text { dijital } & \text { oyun } \\
\text { bağımlılık } & \text { düzeyleri } & \text { (oranları) } \\
\text { nedir? } & & \end{array}$ & Nicel Yöntem & 225 Çocuk & $\begin{array}{l}\text { Dijital Oyun Bağımlılığı } \\
\text { Ölçeği }\end{array}$ \\
\hline $\begin{array}{l}\text { 2.Özel kolejde okuyan, dijital } \\
\text { oyun bağımlısı olan çocukların } \\
\text { aile yapısı ile dijital oyun } \\
\text { bağımlısı olmayan çocukların } \\
\text { aile yapısı nasıldır? }\end{array}$ & Nitel Yöntem & $\begin{array}{l}20 \text { Ebeveyn (anne } \\
\text { ya da babadan biri) }\end{array}$ & $\begin{array}{l}\text { Yarı Yapılandırılmış } \\
\text { Görüşme Formu }\end{array}$ \\
\hline $\begin{array}{l}\text { 3.Özel kolejde okuyan, dijital } \\
\text { oyun bağımlısı olan çocukların } \\
\text { aile ilişkileri ile dijital oyun } \\
\text { bağımlısı olmayan çocukların } \\
\text { aile ilişkileri nasıldır? }\end{array}$ & Nitel Yöntem & $\begin{array}{l}20 \text { Ebeveyn (anne } \\
\text { ya da babadan biri) }\end{array}$ & $\begin{array}{l}\text { Yarı Yapılandırılmış } \\
\text { Görüşme Formu }\end{array}$ \\
\hline $\begin{array}{l}\text { 4.Ebeveynlerin çocuklarının } \\
\text { dijital oyun oynamasına ilişkin } \\
\text { tutum ve davranışları nasıldır? }\end{array}$ & Nitel Yöntem & $\begin{array}{l}20 \text { Ebeveyn (anne } \\
\text { ya da babadan biri) }\end{array}$ & $\begin{array}{l}\text { Yarı Yapılandırılmış } \\
\text { Görüşme Formu }\end{array}$ \\
\hline
\end{tabular}

Tablo 1'deki alt problemlere yanıt aranması, aynı zamanda çalışmanın temel problemine yanıt sağlamıştır. Çalışmanın yöntemine ilişkin bu bilgiler, aşağıda detaylı olarak alt başlıklar halinde açıklanmıştır. 


\section{Çalışmanın Modeli}

$\mathrm{Bu}$ çalışmada karma yöntem türlerinden açıklayıcı model kullanılmıştır. Karma yöntem araştırmaları, araştırmacının bir çalışma veya birbirini izleyen çalışmalar içerisinde nitel ve nicel yöntem, yaklaşım ve kavramları birleştirmesi olarak tanımlanır (Baki ve Gökçek, 2012). Açıklayıcı model ise; birinci aşamada nicel verilerin toplandığı ve daha sonraki aşamada bu bulguların kullanıldığı çalışmalardır (Creswell, 2014). Bu çalışmada çocuklardan nicel veri, ebeveynlerden ise nitel veriler toplanmıştır. Çocukların dijital oyun bağımlılık düzeylerini betimlemeye yönelik toplanan veriler çalışmanın nicel boyutunu; çocukları dijital oyun bağımlısı olan ebeveynler ile çocukları dijital oyun bağımlısı olmayan ebeveynlerle yapılan görüşmeler ise çalışmanın nitel boyutunu oluşturmuştur.

Çocukların dijital oyun bağımlılı̆̆ı düzeyleri çeşitli değişkenlere göre betimlenmiştir. $\mathrm{Bu}$ kapsamda çocuklarda dijital oyun bağımlığı cinsiyete, sınıf düzeyine ve yaşa göre incelenmiş, özel kolejde okuyan sosyo-ekonomik durumu iyi olan çocukların dijital oyun bağımlılık durumları (oranları) betimlenmiştir. $\mathrm{Bu}$ değişkenlere yönelik betimlemeler, çalışmada elde edilen bulgu ve sonuçların hangi özellikteki gruplara genellenebilirliği yönünde katkı sunmuştur. Nicel değişkenler betimlendikten sonra dijital oyun bağımlısı olan çocukların aile profilleri ile dijital oyun bağımlısı olmayan çocukların aile profilleri arasındaki farklılıklar detaylı olarak incelenmiş ve karşılaştırılmıştır. Bu nedenle çalışmada karma yöntemin kullanılması tercih edilmiştir.

\section{Çalışmanın Örneklemi}

Dijital oyun bağımlılı̆̆ının ekonomik durumu iyi olan çocuklar arasında daha yaygın olduğu gözlemlenmektedir. Kayri ve Günüç (2016) yaptıkları bir çalışmada, sosyo-ekonomik düzeyi yüksek olan ailelerin çocuklarının internet bağımlısı olma risklerinin daha fazla olduğunu ortaya koymuşlardır. $\mathrm{Bu}$ nedenle çalışmada amaçlı örnekleme yöntemi kullanılmıştır. Çalışmanın amacı doğrultusunda veriler bir özel kolejden toplanmıştır. Çalışmanın örneklemini oluşturan ebeveynler sosyo-ekonomik düzey bakımından belli bir seviyenin üzerinde bulunmaktadır. Okul idaresi ve rehberlik servisi ile yapılan görüşmeler sonucunda, okulun profilini oluşturan ebeveynlerin her ikisinin de genellikle çalışan bireyler olduğu ve ekonomik durumlarının bölgedeki ortalama sosyo-ekonomik düzeye göre daha iyi olduğu tespit edilmiştir. Her bir çocuk için anne veya babadan biri ile görüşme gerçekleştirilmiştir. Çalışmaya katılacak ebeveynler seçilirken okulun rehberlik servisi ile beraber çalışılmış ve anne ya da babadan hangisi çocuğunun eğitimiyle daha çok ilgilenmişse görüşme onunla yapılmıştır. Çalışmaya katılan ebeveynlerin iletişim bilgileri okul 
idaresinden izin alınarak alınmış ve ebeveynlerden gönüllü olanlarla görüşmeler yapılmıştır. Ebeveynlerden bazıları ile yüz yüze görüşmeler yapılarak ses kaydı alınmış, yüz yüze görüşmenin olanaklı olmadığı ebeveynlerle ise telefonda ses kaydı alınarak görüşmeler yapılmıştır.

Çalışmanın nicel örneklemi. Çalışmanın nicel örneklemini; 2015-2016 EğitimÖğretim yılı bahar döneminde Van ili Merkez ilçesinde bulunan özel bir kolejin ortaokulunda (5., 6., 7. ve 8. sinıflar) eğitim gören çocuklar oluşturmuştur.

Çalışmanın nitel örneklemi. Çalışmanın nitel örneklemini, dijital oyun bağımlılığı ölçeği sonucuna göre; oyun bağımlılık puanları en yüksek olan çocukların ebeveynleri ile oyun bağımlılık puanları en düşük olan çocukların ebeveynleri oluşturmuştur. Her iki gruptan 10 'ar ebeveyn ile görüşme yapılmıştır. Görüşmeyi istemeyen ya da ulaşılamayan ebeveyn olduğunda en yüksek bağımlılık puanına sahip veya en düşük bağımlılık puanına sahip bir sonraki ebeveynle görüşme yapılmıştır. Katılımcıların kimliklerinin gizli tutulması için dijital oyun bağımlısı olan çocukların ebeveynleri "B1..B10” (Bağımlı1..Bağımlı10), dijital oyun bağımlısı olmayan çocukların ebeveynleri ise "BD1..BD10" (Bağımlı Değil1..Bağımlı Değil10) şeklinde kodlanmıştır. Görüşmelere ilişkin bilgiler Tablo 2’te sunulmuştur.

Tablo 2.

Ebeveynlerle Yapılan Görüşmelere İlişkin Bilgiler

\begin{tabular}{llll}
\hline Kodu & Cinsiyeti & Görüşme Süresi (dk:sn) & Kayıt Tarihi \\
\hline B1 & Erkek & $09: 35$ & 12.04 .2016 \\
B2 & Erkek & $09: 22$ & 13.04 .2016 \\
B3 & Erkek & $05: 18$ & 14.04 .2016 \\
B4 & Erkek & $07: 57$ & 12.04 .2016 \\
B5 & Erkek & $18: 36$ & 12.04 .2016 \\
B6 & Erkek & $05: 44$ & 12.04 .2016 \\
B7 & Erkek & $16: 13$ & 14.04 .2016 \\
B8 & Erkek & $18: 05$ & 14.04 .2016 \\
B9 & Erkek & $17: 09$ & 14.04 .2016 \\
B10 & Kadın & $08: 48$ & 13.04 .2016 \\
BD1 & Erkek & $10: 54$ & 13.04 .2016 \\
BD2 & Erkek & $11: 06$ & 13.04 .2016 \\
BD3 & Erkek & $17: 43$ & 12.04 .2016 \\
BD4 & Erkek & $05: 04$ & 12.04 .2016 \\
BD5 & Erkek & $05: 50$ & 15.04 .2016 \\
BD6 & Kadın & $04: 50$ & 14.04 .2016 \\
BD7 & Kadın & $15: 22$ & 14.04 .2016 \\
BD8 & Kadın & $14: 21$ & 14.04 .2016 \\
BD9 & Kadın & $13: 28$ & 15.04 .2016 \\
BD10 & Kadın & $07: 25$ & 15.04 .2016 \\
\hline
\end{tabular}

Tablo 2'de görüldüğü üzere, toplamda 14 baba ve 6 anne ebeveyn ile görüşme gerçekleştirilmiştir. Görüşmeler 12.04.2016-15.04.2016 tarihleri arasında gerçekleştirilmiştir. 


\section{Veri Toplama Araçları}

Nicel veri toplama araçları. Bu çalışmada nicel veri toplama aracı olarak Günüç ve Kayri (2010) tarafından geliştirilen İnternet Bağımlılık Ölçeği, Dijital Oyun Bağımlılı̆̆ı Ölçeği’ne (DOBÖ) uyarlanarak kullanılmıştır. Ölçek maddelerinin doğru anlaşılabilmesi için çocuklar ölçme aracı uygulanmadan önce çalışma hakkında bilgilendirilmiştir.

Dijital Oyun Bağımlılı̆̆ı Ölçeği (DOBÖ). Çalışmada veri toplama aracı olarak Günüç ve Kayri (2010) tarafından geliştirilen İnternet Bağımlılık Ölçeği kullanılmıştır. Çünkü bu ölçek yıllar içinde birçok çalışmada ve farklı örneklemde kullanıldığından ve yapı geçerliliği defalarca test edildiğinden dolayı oldukça güçlü bir araçtır. Ölçeğin orijinalinde bulunan 'internet' kavramı yerine 'dijital oyun’ kavramı kullanılmış ve ölçeğin doğrulayıcı faktör analizi yapılmıştır. Uyarlanan ölçeğin Cronbach alfa $(\alpha)$ iç tutarlık güvenirlik katsayısı 95 olarak bulunmuştur. Ölçeğin orijinali toplam 35 maddeden oluşmakta olup, maddeler beşli likert tipinde hazırlanmıştır. Ölçek toplam dört faktörden oluşmaktadır. Bu faktörler; "Yoksunluk", "Kontrol Güçlüğü", "İşlevsellikte Bozulma” ve "Sosyal İzolasyon" şeklindedirler. Uyarlanan Dijital Oyun Bağımlılığı ölçeği ile çocukların dijital oyun bağımlılık düzeylerinin belirlenmesi amaçlanmıştır. Ölçeği oluşturan maddeler beşli likert tipi “1” (kesinlikle katılmıyorum) ile " 5 " (kesinlikle katılıyorum) şeklinde 1'den 5'e doğru sırayla derecelendirilmiştir. Tüm maddelere cevap verildiği takdirde ölçekten alınabilecek en düşük puan 35 , en yüksek puan ise $175^{\prime}$ tir. Uyarlanan ölçeği oluşturan maddeler arasında “Oyun oynamadığım zaman kendimi gergin/huzursuz hissederim”, “oyun oynamamı sınırlamakta ya da kontrol etmede güçlük çekerim”, "istediğim zamanda oyunun başından kalkamam", "oyunsuz bir yaşam bana anlamsı/boş gelir", "oyun oynamak isteyip de oynayamadığım zaman sinirli olurum”, "oyun oynamamdan dolayı ailemle sorunlar yaşarım” gibi ifadeler yer almaktadır. Gerekli düzenlemeler yapılarak son şekli verilen DOBÖ tamamlandıktan sonra doğrulayıcı faktör analizine ilişkin uygulama ve analizlere geçilmiştir. DOBÖ Ek A'da sunulmuştur.

Nitel veri toplama araçları. Ölçek sonuçlarına göre dijital oyun bağımlısı olan ve dijital oyun bağımlısı olmayan çocukların ebeveynleri (anne ya da babadan biri) ile yarı yapılandırılmış görüşme formu yoluyla nitel veriler toplanmıştır. Yarı yapılandırılmış görüşme formunda genel olarak, aile profilleri, aile yapıları, ebeveynlerin dijital oyunlara karşı tutum ve davranışları, çocuklarıyla olan ilişskileri, dijital oyunların içeriği hakkındaki bilgileri, çocuklarının oynadıkları oyunlara müdahale etme durumları, çocuklarına model 
olabilme gibi konulara ilişkin sorular yer almıştır. Yukarıdaki sorular katılımcılara yöneltilmiş fakat cevap verip vermemeleri onların gönüllülügüne bırakılmıştır.

\section{Verilerin Analizi}

Nicel verilerin analizi. Dijital oyun bağımlılığı ölçeği sonucu veriler toplanmış ve nicel verilerin analizinde; ortalama, standart sapma, yüzde ve frekans gibi betimsel istatistikler kullanılmıştır. Bağımlı olan ile bağımlı olmayan grupların belirlenmesinde ise iki aşamalı kümeleme analizi kullanılmıştır. Genel olarak kümeleme analizi, benzerlik veya uzaklık ölçütlerinden yararlanılarak yapılmaktadır. Bu çalışmadaki analiz için "uzaklık" yöntemi olarak Log-likelihood tercih edilmiştir. Bunun yanında, homojen alt gruplar oluşturmada ise alanyazında önerildiği üzere Bayesçi Bilgi Ölçütü kullanılmıştır (Kayri, 2007). Nicel verilerin analizinde özellikle çocukların profillerini betimleme ve bağımlı olan ile bağımlı olmayan çocukları belirleyerek bu bağlamda ebeveynlerine ulaşmak amaçlanmıştır.

Nitel verilerin analizi. Nitel verilerin analizinde araştırmacılar tarafından geliştirilen yarı yapılandırılmış görüşme formu kullanılmıştır. Görüşme soruları hazırlanarak uzman görüşüne sunulmuş ve görüşme formuna son şekli verilmiştir. Görüşme yapılan ebeveynlerden yazılı izin alındıktan sonra ses kaydı alınarak görüşmeler gerçekleştirilmiştir. Görüşme başlamadan önce ebeveynler çalışma hakkında bilgilendirilmiştir. Yüz yüze görüşmeyi kabul eden ebeveynlerle belirttikleri tarih ve saatte iş yerlerinde görüşülmüş, sorular sorulmuş ve görüşme kayıt altına alınmıştır. Yüz yüze görüşmeyi kabul etmeyen ebeveynlere ise telefonla ulaşılmış, uygun gördükleri tarih ve saatte telefonda görüşme yapılarak izinleri dâhilinde konuşma kaydedilmiştir. Ses kayıtları daha sonra metne dönüştürülüp, metin üzerinden içerik analizi yapılarak veriler ana tema ve alt temalar şeklinde kategorileştirilmiştir.

Nitel verilerin güvenirlik ve geçerliğini sağlamak amacıyla; (i) yapılan görüşmeler için ebeveynlerden sözlü ve yazılı izin alınmış, görüşmeler kayıt altına alınmıştır; (ii) ebeveynlerle yapılan görüşmelerin tarihi, saati, görüşme süresi gibi bilgiler Tablo 2'de verilmiştir; (iii) kayıtlar daha sonra metne dönüştürülmüş ve metinler içerik analizi yöntemiyle alan uzmanı iki kişi tarafından temalar halinde kodlanmış, alan uzmanları tarafindan ortak bir görüş oluşuncaya kadar değerlendirmeye devam edilmiştir. Kodlamalar sonucunda ana tema ve alt temalar oluşturulmuştur; (iv) veriler raporlaştırılırken ilgili temalara ilişkin katılımcı ifadeleri doğrudan alıntı yapılarak verilmiştir. 
Ölçeğin uyarlanmasına ilişkin verilerin analizi. Ölçek uyarlaması yapılırken İnternet Bağımlılık Ölçeği’nde yer alan "internet” kavramı "dijital oyun” kavramı ile değiştirilmiş ve ölçek uygulaması yapıldıktan sonra ilk olarak güvenirlik ardından geçerlik analizleri yapılmıştır. Maddelerin güvenirlik analizi için, iç-tutarlılık katsayısı $(\alpha)$ değeri hesaplanmıştır. Daha sonra doğrulayıcı faktör analizi (DFA) yapılarak elde edilen modelin uygunluğu incelenmiştir. Bu işlem için $\chi^{2}$ (Chi-Square Goodness of Fit), CFI (Comparative Fit Index), NFI (Normed Fit Index), NNFI (Not-Normed Fit Index), RMR (Root Mean Square Residuals), SRMR (Standardized Root Mean Square Residuals) ve RMSEA (Root Mean Square Error of Approximation) kriterleri ölçüt olarak kullanılmıştır.

DOBÖ uyarlamasına ilişkin bulgular. Bu çalışma için veriler toplam 225 ortaokul öğrencisinden toplanmıştır. DFA, kayıp verilere karşı duyarlı olduğu için veri setinde kayıp verilerin olmaması önerilmektedir. $\mathrm{Bu}$ nedenle kayıp veri girişi yaptığı belirlenen 20 katılımcı veri setinden çıkartılmış ve DFA için analizler 205 katılımcı üzerinden gerçekleştirilmiştir.

Doğrulayıcı faktör analizi (DFA). DFA ile 35 madde ve dört faktörden oluşan DOBÖ yapısının doğruluğu test edilmiştir. Aşağıda yer alan Tablo 3'te DFA'ya ilişkin çıktılar betimlenmiş ve $t$ değerleri, faktör yükleri ve madde-toplam korelasyonları değerlendirilmiştir.

Tablo 3.

DFA Bulgularına İlişkin Madde İstatistikleri

\begin{tabular}{|c|c|c|c|c|c|}
\hline Madde & $T$ & Faktör Yükü & Madde-Toplam Korelasyonu (r) & Ort. & $\mathrm{S}$ \\
\hline Faktör1 & & $\alpha=.86$ & & & \\
\hline M1 & -- & .70 & .66 & 2.43 & 1.34 \\
\hline M2 & 9.80 & .72 & .57 & 2.78 & 1.50 \\
\hline M3 & 8.50 & .62 & .47 & 3.27 & 1.58 \\
\hline M4 & 8.50 & .63 & .45 & 2.77 & 1.38 \\
\hline M5 & 8.49 & .62 & .52 & 2.80 & 1.57 \\
\hline M6 & 9.95 & .73 & .62 & 2.80 & 1.52 \\
\hline M7 & 9.11 & .67 & .57 & 2.28 & 1.38 \\
\hline M8 & 9.74 & .72 & .60 & 2.59 & 1.45 \\
\hline M9 & 7.85 & .58 & .54 & 2.24 & 1.46 \\
\hline M10 & 9.67 & .71 & .62 & 2.69 & 1.47 \\
\hline M11 & 9.55 & .70 & .68 & 2.29 & .1 .39 \\
\hline Faktör2 & & $\alpha=.90$ & & & \\
\hline M12 & -- & .75 & .60 & 2.34 & 1.40 \\
\hline M13 & 10.33 & .71 & .67 & 1.80 & 1.18 \\
\hline M14 & 10.71 & .73 & .65 & 2.42 & 1.42 \\
\hline M15 & 9.19 & .64 & .56 & 2.64 & 1.42 \\
\hline M16 & 11.20 & .76 & .69 & 2.36 & 1.46 \\
\hline M17 & 9.95 & .68 & .61 & 2.28 & 1.47 \\
\hline M18 & 12.03 & .81 & .75 & 2.04 & 1.30 \\
\hline M19 & 10.56 & .72 & .66 & 2.05 & 1.32 \\
\hline M20 & 10.75 & .73 & .69 & 1.95 & .1 .23 \\
\hline M21 & 11.12 & .76 & .72 & 2.05 & 1.39 \\
\hline
\end{tabular}


Tablo 3. devam

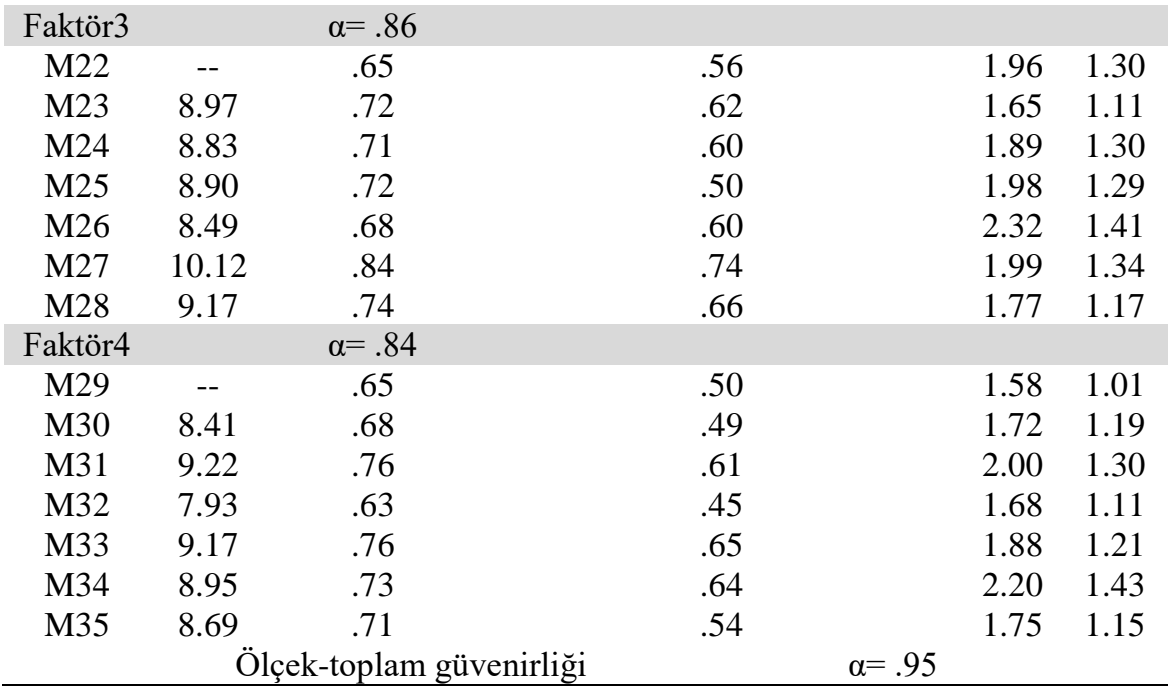

Ölçekteki her göstergenin $t$ değerinin $\pm 1,96$ ( $\mathrm{p}<.05$ düzeyinde) aralığı dışında olması önerilmektedir (Kline, 2011; Tabachnick ve Fidell, 2007). Tablo 3 'ten anlaşılacağı üzere her göstergenin $t$ değerinin $\pm 1,96$ ' dan büyük olduğu ve maddelerin $t$ değerlerinin yüksek düzeyde olduğu (7.93-12.03 aralığı) görülmektedir.

Ölçme modelinin uyum indekslerine bakıldığında, ilk olarak $\chi 2$ değerine ilişkin $p$ düzeyine bakılmıştır. $p$ değerinin .05 'ten büyük olması iyi uyuma işaret etmektedir. $\mathrm{Bu}$ çalışmada ki-kare değeri $\chi^{2}=1424,64(p=.15)$ ve serbestlik derecesi $\mathrm{sd}=556$ olarak hesaplanmıştır. Dolayısıyla $\chi 2 /$ sd $(1424,64 / 556)$ oranı hesaplanmış ve 2,56 olarak bulunmuştur. $\mathrm{Bu}$ değerin 2 ya da 3'ün altında olması iyi uyuma karşılık gelmektedir (Tabachnick ve Fidell, 2007). Ayrıca diğer uyum indeksleri de alanyazına göre değerlendirilmiştir. DFA'ya ilişkin uyum indeksleri incelendiğinde, yaygın olarak kullanılan doğrulama faktör analizi kriteri RMSEA $\leq .08$ olarak hesaplanmıştır (Sümer, 2000; Brown, 2006; Hooper, Coughlan ve Mullen, 2008). Genel olarak değerlendirildiğinde faktör yapıs1 olarak tanımlanan modelin doğrulandı̆̆ı gözlemlenmiştir. DFA sonucunda güvenirlik katsayıları ölçeğin tamamına ilişkin $\alpha=.95$; diğer alt faktörlere ilişkin ise sırasıyla $\alpha=.86$, $\alpha=.90, \alpha=.86$ ve $\alpha=.84$ olarak hesaplanmıştır.

\section{Bulgular}

\section{Verilerin Analizlere Hazırlanması}

$\mathrm{Bu}$ çalışmada dijital oyun bağımlılığı ölçeği toplam 229 katılımcıya uygulanmış ve veriler SPSS 18.0 paket programına girilmiştir. Veriler kontrol edilerek analizlere hazır hale getirilmiştir. Tutarlı yanıtlar vermeyip, rastgele veri girişi yaptığı düşünülen 4 katılımcı 
değerlendirilmeye alınmamıştır. Analizler toplam 225 katılımcı ile gerçekleştirmiştir. Verilerin normal dağılım gösterip göstermediği histogram, çarpıklık-basıklık değerleri, Q-Q ve P-P grafikleri ile incelenmiştir. Çarpıklık katsayısının \pm 1 sınırları içerisinde kalması, verilerin normal dağılımdan aşırı bir sapma göstermediği anlamına gelebilir (Büyüköztürk, 2014). Ölçeğin toplam puanına ilişkin çarpıklık $(.56 ; \pm 1)$ ve basıklık $(-.50 ; \pm 1)$ değerlerinin belirlenen sınırlar içerisinde olması ve histogram, P-P ve Q-Q grafiğinin incelenmesi sonucu dağılımın normal olduğuna karar verilmiştir.

\section{Demografik Değişkenlere ait Betimleyici İstatistikler}

Çalışmanın bu kısmında bazı demografik değişkenlere ait betimleyici istatistikler sunulmuştur. Cinsiyet, sınıf, yaş, evde internet erişimi, dijital oyunların oynandığı araçlar, ebeveynlerin kullandığı teknolojik araçlar, çocuğun internette oyun oynama durumu, çocuğun günlük ortalama kaç saat dijital oyun oynadığı değişkenlerine ait yüzde ve frekans dağılımları Tablo 4'te betimlenmiştir.

Tablo 4.

Katılımcıların Demografik Değişkenlere Göre Dağılımları

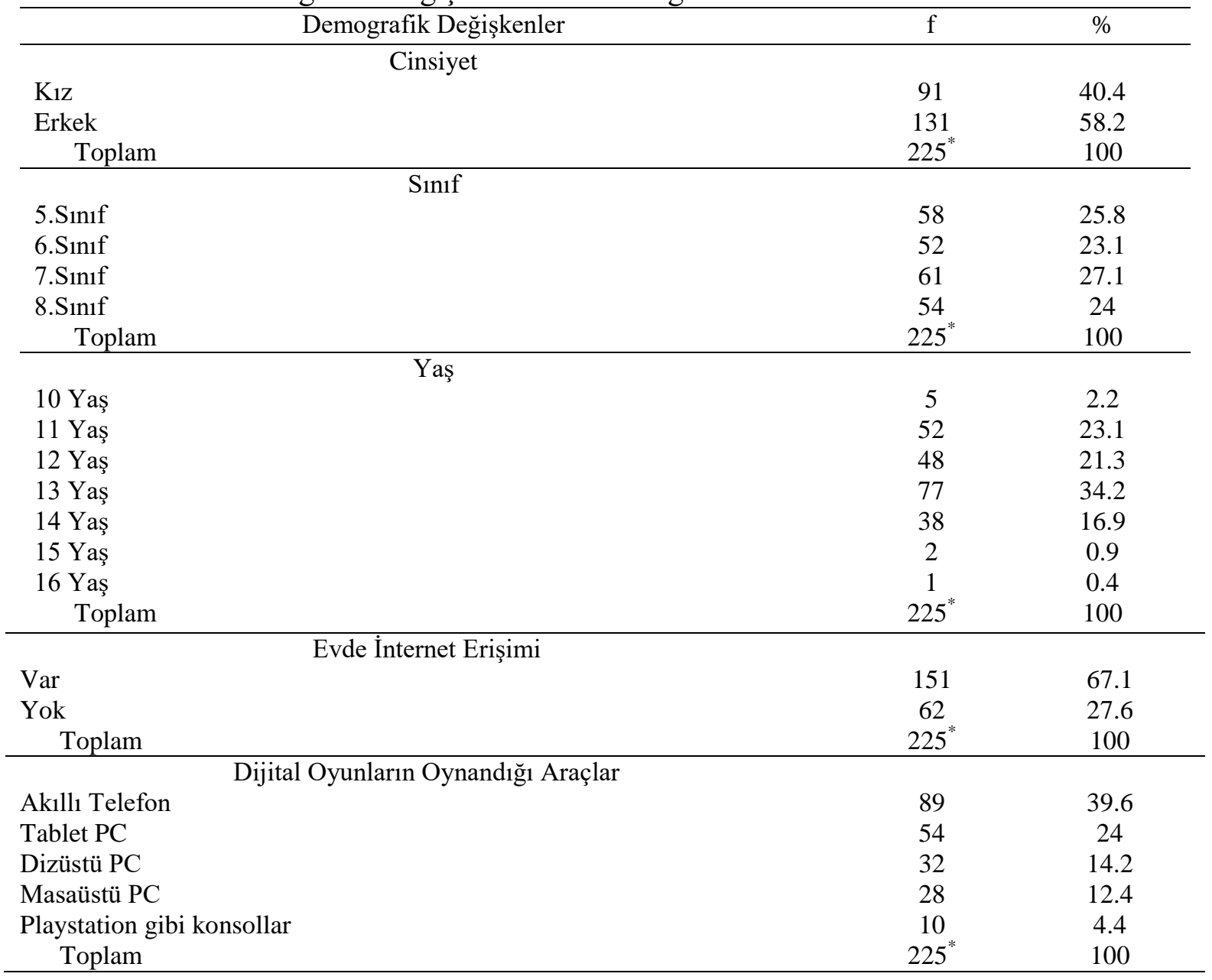


Tablo 4. Devam

\begin{tabular}{|c|c|c|}
\hline \multicolumn{3}{|c|}{ Öğrenci Babalarının Dijital Cihazları Kullanma Süresi } \\
\hline Hiç Kullanmaz & 10 & 4.4 \\
\hline 1 Saatten az & 29 & 12.9 \\
\hline 1-2 Saat & 65 & 28.9 \\
\hline 3-4 Saat & 28 & 12.4 \\
\hline 5-6 Saat & 24 & 10.7 \\
\hline 7 Saatten fazla & 28 & 12.4 \\
\hline Toplam & $225^{*}$ & 100 \\
\hline \multicolumn{3}{|c|}{ Öğrenci Annelerinin Dijital Cihazları Kullanma Süresi } \\
\hline Hiç Kullanmaz & 19 & 8.4 \\
\hline 1 Saatten az & 43 & 19.1 \\
\hline 1-2 Saat & 69 & 30.7 \\
\hline 3-4 Saat & 27 & 12 \\
\hline 5-6 Saat & 13 & 5.8 \\
\hline 7 Saatten fazla & 12 & 5.3 \\
\hline Toplam & $225^{*}$ & 100 \\
\hline \multicolumn{3}{|c|}{ Çocukların İnternette Oyun Oynama Durumu } \\
\hline Evet & 135 & 60 \\
\hline Hayır & 71 & 31.6 \\
\hline Toplam & $225^{*}$ & 100 \\
\hline \multicolumn{3}{|c|}{ Çocukların Günlük Dijital Oyun Oynama Süresi } \\
\hline Her gün oynamıyorum & 102 & 45.3 \\
\hline 1 Saatten az & 50 & 22.2 \\
\hline 1-2 Saat & 55 & 24.4 \\
\hline 3-4 Saat & 10 & 4.4 \\
\hline 5-6 Saat & 3 & 1.3 \\
\hline 7 Saatten fazla & 2 & 0.9 \\
\hline Toplam & $225^{*}$ & 100 \\
\hline
\end{tabular}

*Not: Cinsiyet sorusuna 3, yaş sorusuna 2, evde internet var mı? Sorusuna 12, dijital oyunların oynandığı araçlar sorusuna 12, babanızın dijital cihazları kullanma süresi? Sorusuna 41, annenizin dijital cihazları kullanma süresi? Sorusuna 42, dijital cihazları kullanma süresi? Sorusuna 41, internette Oyun Oynama Durumu sorusuna 19, günlük dijital oyun oynama süresi? Sorusuna 3 katılımcı geçersiz cevap vermiştir.

Tablo 4'de görüldüğü üzere, çocukların \%60’1 (135 kişi) internette oyun oynadığını belirtmişken, \%31,6'sı (71 kişi) ise internette oyun oynamadığını belirtmiştir. Çocukların çoğunluğunun internette oyun oynadığı görülmüştür. İnternette oynamadığını belirten çocukların, interneti sadece ADSL bağlantısı şeklinde algıladıkları akıllı telefon, tablet gibi cihazlardaki interneti değerlendirmeye almadıkları düşünülmektedir. Çocukların günlük ortalama kaç saat dijital oyun oynadıkları da betimlenmek istenmiştir. Tablo 4 incelendiğinde özellikle de 3-4 saat oynuyorum diyenlerin \%4,4 (10 kişi), 5-6 saat oynuyorum diyenler \%1,3 (3 kişi), 7 saatten fazla oynuyorum diyenler ise \%0,9 (2 kişi) olarak belirlenmiştir.

\section{Çocukların Dijital Oyun Bağımlılık Düzeylerine İlişskin Bulgular}

Çalışmanın birinci alt probleminde; özel kolejde okuyan çocukların dijital oyun bağımlılığı düzeylerinin belirlenmesi amaçlanmıştır. Bu bağlamda çocukların dijital oyun bağımlılığı düzeylerini belirlemek için iki aşamalı kümeleme analizi uygulanmış ve analiz bulguları Tablo 5 'te verilmiştir. 
Tablo 5 .

DOBÖ Puanlarının İki Așamalı Kümeleme Analizi ile Gruplandırılması

\begin{tabular}{lcccc}
\hline Kümeleme & $\mathrm{N}$ & Ort. & $\mathrm{S}$ & $\%$ \\
\hline Bağımlı Olmayan Grup & 92 & 44.31 & 8.30 & 40.9 \\
Risk Grubu & 99 & 81.61 & 11.89 & 44 \\
Bağımlı Grup & 34 & 123.85 & 12.76 & 15.1 \\
\hline \multicolumn{1}{c}{ Toplam } & 225 & & & 100 \\
\hline
\end{tabular}

Tablo 5'te görüldüğü üzere çalışma örneklemi bağımlılık puanları üzerinden üç gruba/kümeye ayrılmıştır. Bu bağlamda, bağımlı olmayan grupta 92 (\%40,9), bağımlılık riski taşıyan grupta 99 (\%44) ve bağımlı grupta ise $34(\% 15,1)$ çocuk yer almıştır.

Birinci grubu oluşturan bağımlı olmayan gruptaki çocuklar DOBÖ ölçeğindeki göstergelerin çoğunu karşılamadığı, buna karşın üçüncü grubu oluşturan bağımlı grubun ise ölçekteki göstergelerin birçoğunu karşıladığı söylenebilir. İkinci grupta yer alan risk grubundaki çocuklar ise DOBÖ ölçeğindeki göstergelerin bir kısmını karşılamakla beraber bir kısmını da karşılamadığg şeklinde yorumlanabilir.

\section{Aile Profillerine İlişkin Bulgular}

Yarı yapılandırılmış görüşmeler sonucu metne aktarılan ses kayıtları içerik analizi yöntemi ile değerlendirilmiştir. İlk olarak alt temalar ortaya çıkartılmış, ardından ana temalar oluşturulmuştur. Ana temalar Aile Yapısı, Aile Iç̧i İletişim ve Dijital Oyun başlıkları şeklinde belirlenmiştir. Çocukları dijital oyun bağımlısı olan ebeveyn grubu ile çocukları dijital oyun bağımlısı olmayan ebeveyn grubu ile yapılan görüşmeler sonucu ortaya çıkarılan ana tema ve alt temalar Şekil 1'de gösterilmiştir. Her ne kadar bu temalar çok kesin çizgiler ile gruplar arasında belirleyici olmasa da, bazı yorumların yapılabilmesi açısından bu genellemeler önemli görülmektedir. 


\begin{tabular}{|c|c|c|c|c|c|}
\hline \multicolumn{2}{|c|}{ Aile Yapısı } & \multicolumn{2}{|c|}{ Aile İçi İletişim } & \multicolumn{2}{|c|}{$\begin{array}{l}\text { Dijiital Oyunlara } \\
\text { Yönelik Görüşler }\end{array}$} \\
\hline $\begin{array}{c}\text { Çocuklan Bağımlı } \\
\text { Olan Ebeveynlere } \\
\text { Ait Temalar }\end{array}$ & \begin{tabular}{|c|} 
Çocukları Bağımlı \\
Olmayan \\
Ebeveynlere Ait \\
Temalar \\
\end{tabular} & \begin{tabular}{|l|l|}
$\begin{array}{l}\text { Çocuklan Bağımh } \\
\text { Olan Eb'sveynlere } \\
\text { Ait Temalar }\end{array}$ \\
\end{tabular} & $\begin{array}{c}\text { Çocukları Bağımlı } \\
\text { Olmayan } \\
\text { Ebeveynlere Ait } \\
\text { Temalar } \\
\end{array}$ & \begin{tabular}{|l|} 
Çocuklan Bağımlı \\
Olan Ebeveynlere \\
Ait Temalar \\
\end{tabular} & \begin{tabular}{|c} 
Çocuklan Bağımlı \\
Olmayan \\
Ebeveynlere Ait \\
Temalar \\
\end{tabular} \\
\hline Muhafazakâr & Muhafazakâr & $\begin{array}{l}\text { letişim } \\
\text { kopukluğu }\end{array}$ & lyi iletişim & \begin{tabular}{|l|}
$\begin{array}{l}\text { Oynatmamak ile } \\
\text { cezalandırma }\end{array}$ \\
\end{tabular} & $\begin{array}{l}\text { Oyun oynamaya } \\
\text { sinır }\end{array}$ \\
\hline iş yoğunluğu & Aile içi etkinlik & ilgisizlik & Çocuğa ilgi & Oyunları takip & Oyunlara yasak \\
\hline Baskıcı baba & Aile içi dürüstlük & \multirow{2}{*}{\begin{tabular}{|l} 
Ebeveyn-çocuk \\
Çatışması
\end{tabular}} & \multirow[t]{2}{*}{ Kuralları olan } & etme & koyabilme \\
\hline \multirow[t]{2}{*}{ Huzursuzluk } & Huzur & & & Suçu çevrede & Teknolojinin \\
\hline & Cocuğa bilinc & \begin{tabular}{|l|}
$\begin{array}{l}\text { Çocuğun yalnız } \\
\text { kalması }\end{array}$ \\
\end{tabular} & \begin{tabular}{|l} 
Babanın arkadaş \\
gibi olması
\end{tabular} & görme & $\begin{array}{l}\text { olumsuzluklarına } \\
\text { karşı bilinç }\end{array}$ \\
\hline \multirow{2}{*}{ Kesin kurallar } & $\begin{array}{l}\text { Çocuga Diınç } \\
\text { kazandırma }\end{array}$ & Annenin daha az & Annenin daha & Çaresizlik & \\
\hline & & toleranslı olması & ilgili olması & \begin{tabular}{|l|}
$\begin{array}{l}\text { Tedaviyi zamana } \\
\text { bırakma }\end{array}$ \\
bı
\end{tabular} & \\
\hline
\end{tabular}

Şekil 1.Görüşmeler Sonucu Ortaya Çıkan Ana Tema ve Alt Temalar.

Aile yapısı temasına ilişkin bulgular. Bağımlı olmayan çocukların aile yapılarında en dikkat çeken temalar; aile yapılarının geniş aile olması, aile içinde bazı net kuralların olması, daha geleneksel bir aile yapısının olması, çocuklarına aile bilinci kazandırma amaçlarının olması, çocuk üzerinde annenin rolünün daha fazla olması gerektiğine inanılması, aile içerisinde huzuru sağlamaya özen gösterilmesi şeklinde sıralanabilir. Çocukları dijital oyun bağımlısı olmayan bazı ebeveynlerin bu konudaki görüşleri şu şekildedir;

...biz büyük aile modeliyiz. Şu an ailenin tek çocuğu eşimde çalışan bir insan. İlgiyi çok görüyor. Babamlar da ilgileniyor. Babamlarla da aynı sitedeyiz. [BD1]

... Doğal davranıyoruz hepimiz birbirimize. Kardeşlerimle bir aradayız aynı binadayız birbirimize karşı doğalız saygılıyız. [BD3]

...ben çocuklarımdan önce evde olurum. Teneffüs aralarında ne yaptıklarını arkadaşları ile ne konuştuklarını tek tek konuşuruz. Anne baba bir olursa istediklerini yapabileceklerine inanıorum ve anne çocuklarına şunlar gitsin de kafamı dinliyeyim dememeli. Güzel bir yemek bile pişse çocuklar mutlu olur. Esas düzeni anne sağlar bence. [BD7] 
...kizımla beraber alışveriş yaparı, canı sikllırsa araba ile geziye çıkarı. Ayrıca kizımı tekvando kursuna yazmışım ve 4.5 yldir lisanli oyuncu olarak devam etmektedir. Şu an 45 yaşındayım, yeri geldiğinde kizımla evde saklambaç oynamışlı̆̆ım bile oluyor...[BD9]

...bizim evimizin hem iç klsminda oyun parkl var hem de dışarıda. Akşamları istedikleri zaman alt tarafa inip oynayabiliyorlar. Ama ders saatinde ödev saatinde mümkün değil buna izin vermiyorum. [BD10]

$\mathrm{Bu}$ temalardan bazıları bağımlı çocukların ailelerinde de görülse bile bu derece ve bağımlı olmayan çocukların ailelerinde olduğu kadar öne çıkmamıştır. Ayrıca bağımlı olan çocukların ailelerinde; anne ve babanın yoğun iş tempolarının olduğu, babanın baskıcı bir tutuma sahip olduğu, aile içerisinde sert kuralların olduğu ve genel olarak bir huzursuzluk durumunun olduğu gibi temalar ortaya çıkmıştır. Örneğin ebeveynler bu konuda şunları söylemiştir;

...işlerimden dolayı çocuğumla günlük ortalama 2 saat geçirebiliyorum. Çocuklar da boş kaldiklarında televizyon veya teknolojik cihazlara yöneliyorlar, dolayısıyla bu konuda sikıntı yaşamaktayız. [B6]

...çocuklarla dışarıya çıkamadığımdan mecburen onlarla evde kalmak zorunda kallyorum. Dört duvar arasinda çocuk ne yapabilir ki? Ya bilgisayar, ya telefon ya da televizyon ile vakit geçirecektir. [B10]

...bizim çocuğumuzla olan iletişimimiz yeri geldiği zaman zorbalı̆ga gidiyor. Kesin kurallar koymamız gerekiyor. Çoğu zaman çocukların sınırı aşma gibi durumları olduğu zaman da çok kesin kurallar koyarız. Mesela öyle zamanlar oluyor ki tableti 15 gün tamamen kaldırıyorum. Ceza uygulamalarl gibi şeyler yapıyoruz. [B2]

...iletişimimiz var ama çok fazla evime ilgi gösteremiyorum. Bu bir eksikliktir. İşim çok yoğun, birkaç yerde işyerim var. Kafam çok yoğundur. [B7]

...aile içerisinde kesin sinırlarımı vardır. $O$ sinır aşılamaz. Herkes istediğini konuşabilir, herkes istediğini yapabilir diye bir şey yoktur. Belli kurallar vardır. [B5]

Çocukları dijital oyun bağımlısı olmayan ailelerde genellikle bir aile bilincinin olduğu, aile içi huzurun tesisine dikkat edildiği, çocuğun kendini aile içerisinde rahat hissettiği, tüm ailenin bir arada bulunduğu zamanların olduğu, çocuğun manevi olarak desteklendiği, annenin çocuk üzerindeki rolüne önem verildiği görülmüştür. Buna karşıın çocukları dijital oyun bağımlısı olan ailelerde ise genel bir huzursuzluk durumunun olduğu, babanın baskıcı bir tutuma sahip olduğu, iş yoğunluğundan dolayı çocuğa yeterli zamanın ayırılmadığı ve aile içerisinde kesin kuralların olduğu görülmüştür. 
Aile içi iletişim temasına ilişkin bulgular. Bağımlı olmayan çocukların aile ilişkilerinde; çocuğun anne ve babasına olumsuz durumları söyleyebilmesi, aile içerisinde iletişimin iyi olması, çocuğa ilgi gösterilmesi, babanın çocuğu ile arkadaş gibi olması, annenin çocuğuna yakın ilgi göstermesi, ebeveynlerin çocuklarına karşı sözlerini tutması, ebeveynlerin çocuğun talep ettiği her şeyi o anda karşılamaması, çocuğa bunun bir zamanının olduğunu ve beklemesi gerektiğini söylemesi gibi temalar öne çıkmıştır.

...kızım zamanının çoğunu benimle geçirir, ben olmadığım zaman ablası veya kuzenleri ile aktiviteler yapar. Bilgisayarda araba oyunu oynar ve oyun oynadĭ̆ zaman da ben yanında olurum. Kızımın bir sıkıntısı olduğunda hemen benimle paylaşır. [BD6]

...aile içinde iletişimde bir sıkıntı yok. Herhangi bir sıkıntısı olduğunda annesine bana rahatlıkla söyleyebilir. Rahatlıkla konuşabiliriz. Hatta bazen hoşnut olmadiğı şeyleri söyleyebilir. Yani şu hareketinizi sevmiyorum. Şu davranışınızı da beğenmiyor diyebilir. Bu beni etkileyebilir. Sürekli ders çalış dememizden hoşnut olmaz demeyin artık bunu der. Okulda ya da bilim sanata gider. Bilim sanatta her hangi bir şey olsa gelir paylaşır. Yeni bir şey ögrense gelir paylaşır. Ya da sorar. O hususta bir sıkıntı yok. [BD2]

...çocuk yeri geldiği zaman bir arkadaş gibi davranıyor. Ne çok baskıcı ne çok rahat tatlı sert bir mantı̆̆l var bizim. Çocuk da aile de çok rahattır benle bir arkadaşı gibi konuşur. Kuralları benden bilir. Kuralların onun iyiliğine olduğunu bilir. Çok baskıdan ziyade belli şeyleri kendi hayatı için yaptığımız imajını veririz. [BD1]

...bu zamanda çocuğunla arkadaş olacaksın ilk önce. Çocuk senle hiçbir şeyini saklamayacak. Fırsat vereceksin. Konuşacaksın. Öğretmen amaçlı konuşacaksın. Her istediğini benimle yüzde 90 paylaşıyor annesi ile yüzde 60 paylaşlyor. Şimdi zaten klz çocuğunun anneden biraz çekinmesi lazım. Abileri ile de iletişimi iyi. [BD5]

Bağımlı olan çocukların aile ilişkilerinde öne çıkan olumsuz temalar ise; aile içerisinde iletişim kopukluğunun olması, çocuğa yeterli ilginin gösterilememesi, çocuğun bazen tek başına kalması, çocuğa aşırı ve abartılı tepkilerin gösterilmesi, annenin çocuğuna karşı daha az toleranslı ve daha çok disiplinli olması, çocuğa hafif ya da ağır şiddet uygulanması, ebeveyn-çocuk çatışmasının yaşanması, çocuğun aileyi reddetmesi, ebeveynçocuk paylaşımının oldukça az olması, anne ve baba arasında çatışmaların olması şeklindedir. Buna ilişkin ebeveyn görüşleri şöyledir;

Benim çocuğum saygısızlık yapamaz, yaparsa onun gözünü çıkarırım. Dayak cennetten çıkmış. Çocuğum hak ederse döverim. Gerektiği zaman dayă̆ı atıyorum ... [B8] 
...çocuğuma hiçbir zaman şiddet uygulamadım diyemem. Babası olarak tokat atmışlığım veya yastıkla kafasına vurduğum olmuştur. [B9]

...erkek çocukları genelde sorunlarını benimle paylaşır ama kız çocuğu ile bazen iletişim çekmede zorlanıyorum. Yeri geldiğinde zorba olabiliyoruz... [B2]

...ben kendi açımdan iyi iletişim kurduğunu düşünüyorum. Bazen de olumsuzluklar olabiliyor. İşte şu an onun ergenlik çağına girmesiyle bizi reddeden tavırları var. Onun dışında klasik anne ve baba tavrının ödev ve eğitim noktasındaki talepleri ile öğrencinin uyuşmazlıkları var, bunlardan doğan problemler var. [B3]

Bağımlı olmayan çocukların aile içi iletişimde annenin despot ve baskıcı olduğu olumsuz bir iletişim şekli görülse de bağımlı olan çocukların aile içi iletişimlerindeki kadar abartılı olmadığı ortaya çıkan bir başka tema olarak görülmüştür.

Dijital oyunlara yönelik görüşler temasına ilişkin bulgular. Çocukları bağımlı olan ailelerin; çocuklarına teknolojiyi kullandırtmayarak ceza vermesi, teknoloji kullanımını takip etmesi, ebeveynlerin çocuklarının teknolojiyi kendilerinden daha iyi kullandığını düşünmesi, çocuklarını teknolojinin olumsuzluklarına karşı korumada önlem almayıp tedavi için zamana bırakılması gerektiğine inanması, okuldaki teknoloji kullanımını tamamen yasaklanmasını istemesi, teknolojiyi olumsuz kullanma hakkında suçu okul ve arkadaş çevresinde bulması ve bu konuda kendilerini çaresiz hissetmesi dijital oyun ana teması altında ortaya çıkan temalar olmuştur.

...teknolojinin doğurabileceği zararları daha önce hiç duymadım. Teknolojinin olumsuz sonuçlarını biliyorum. (B4)

...sonuçta telefon çocuğun eline geçtiği an oyun oynamaya çalışlyor, ne kadar engellesek de bazen engel olamıyoruz. Örneğin diyor ki, ver foto çekeyim bir iki foto çekiyorum bir bakıyorum oyuna girmiş. Çocuk çok bağıml, ben böyle bir şey görmedim. [B6]

...çocuğum özellikle tatillerde teknolojik cihazları çok kullanır. Nasıl bir bă̆ımlılıksa engel olamıyorum. Çocuk bir şeyi yapmak isterse senin orda yapmaz, gider internet kafede yapar ya da başkasının şifresi ile girer. Yapmak isterse yapar. Çözüm değil o. [B7]

...çocuğuma eğer dönem sonunda takdir belgesi getirirse son model akullı telefon alacağımı söyledim ve aldım. Doğru mu yaptım yanlış mı yaptım bilmiyorum... [B8]

...çocuğum çok aşırl oynar, ben desem ki 24 oyna yok demez. Her tarafta televizyon, telefon hepsi teşvik ediyorlar. Ne kadar engellesek de bazen engel olamıyoruz. [B6] 
Çocukları bağımlı olan ve çocukları bağımlı olmayan her iki aile grubunda da genel olarak teknolojinin olumsuzluklarına karşı bir bilincin olduğu teması ortaya çıkmıştır. Ayrıca çocukları bağımlı olmayan ailelerin çocuklarının oyun oynamasına sınır getirmesi, çocuklarını kontrol etmesi, teknoloji kullanımını mümkün olabildiği kadar yasaklaması da bir başka tema olarak ortaya çıkmıştır.

...teknolojinin zararlı yönlerini, faydalı boyutlarını çocuğa anlatırım. Mesela Google’ı kullanırken bilgi amaçlı kullanmalarını söylerim. Çocuğa daha önce tablet aldık. Oyunlarla belli bir zaman ayırması gerektiğini dersleriyle de ilgilenmesi gerektiğini bildirdik. [BD1]

...çocuğum okul başladığından beri telefonu almıyor eline sadece bir ödev olduğunda alır ödeve bakar. Diğer türlü hiç oynamaz. Bilgisayarı bazen hafta sonu bir oyun oynayacaksa açıyoruz, o da çok az... [BD6]

...çocuğum okuldan gelince oynaması için kendi telefonumu veriyorum ve sürekli kontrol ediyorum. Televizyonda hangi programları izlediğini takip ediyorum. İzlediği kanallar kontrolümüz altında zaten... [BD9]

...oyun oynarken kendi haline biraklyoruz ama hatırlatma yapıyoruz. Arada bir kapısını tıklatıp bak süren doldu diye hatırlatıyoruz. O da tamam diyor ama tamam demesi yetmiyor. Birkaç defa tekrar etmemiz gerekiyor bunu söylemezseniz devam ediyor. Uyarmanız gerekiyor sürekli. [BD2]

Yukarıdaki tüm bilgiler dikkate alındığında; çocukları dijital oyun bağımlısı olan aileler ile çocukları dijital oyun bağımlısı olmayan aileler arasında aile yapıları bakımından bazı benzerlikler olsa da genel olarak aile profilleri bu konuda birbirinden farklılık göstermektedir. Örneğin; çocukları dijital oyun bağımlısı olan ailelerin; çocuklarına daha az ilgi gösterdiği, teknolojinin olumsuz yönlerine karşı kendilerini çaresiz hissettikleri ve bu konuda çocuklarına teknolojiyi tamamen yasaklayabildikleri görülmüştür. Ebeveynlerin çocukları ile olan iletişimlerinde bazı problemler yaşadığı, çocuklarına hafif veya ağır şiddet uygulayabildiği ortaya çıkmıştır. Ebeveynlerin teknolojinin olumsuz yönleri hakkında bilinçli olduğu fakat bu konuda çocuklarını yönlendirmede sıkıntılar yaşadığı, teknolojiyi tamamen yasaklama yoluna gittikleri görülmüştür. Ayrıca ebeveynlerin çocuklarının dijital oyun bağımlısı olmaları hakkında suçu çocuklarının arkadaş çevresinde ya da okudukları okulda gördükleri de ortaya çıkmıştır. 
Dijital oyun bağımlısı olmayan çocukların aile yapıları incelendiğinde ise; ailelerin geniş olduğu, aile içinde bir huzur ortamının hâkim olduğu, aile içerisinde kesin yasakların değil de daha çok belli kuralların olduğu, çocukların her istediği teknolojik cihazın hemen alınmadığı, çocukların oynadığı dijital oyunları sınırlandırdığı görülmüştür. Ayrıca ebeveynlerin çocuklarla beraber etkinlikler yaptığı, aile bireylerinin çocuğa yakın ilgi gösterdiği, özellikle annenin çocuğuyla olumlu bir iletişim kurduğu da ortaya çıkmıştır.

Her iki aile grubundan ebeveynlerin kendi ailelerini muhafazakâr olarak nitelediği, çocuklarını İslami ahlakla büyütmeye çalıştığı, teknolojinin olumsuz yönlerinden haberdar oldukları da çalışmanın bulguları arasında yer almıştır.

\section{Tartışma ve Sonuç}

$\mathrm{Bu}$ çalışmada, çocukları dijital oyun bağımlısı olan ebeveynler ile çocukları dijital oyun bağımlısı olmayan ebeveynlerin ailelerinin bazı değişkenler açısından incelenmesi amaçlanmıştır. Bu kapsamda, dijital oyun bağımlılığına ilişkin daha derin verilere ulaşllabilmek için teknolojiye erişim konusunda problem yaşamayan ekonomik düzeyi iyi olan aileler tercih edilmiştir. Bu nedenle çalışmada amaçlı örnekleme yöntemi kullanılmış, sosyo-ekonomik düzey bakımından iyi durumda olan ve teknolojik cihazlara erişim konusunda olanaklara sahip ailelerin bulunduğu özel bir kolej seçilmiştir.

Çalışmada öncelikle çocukların bağımlılık durumları nicel olarak betimlenmiştir. Buna göre çocukların \%40,9'unun dijital oyun bağımlısı olmadığg, \%44'ünün risk grubunda olduğu ve \%15,1'inin ise dijital oyun bağımlısı olduğu sonucuna ulaşılmıştır. Bu sonuçlar Yılmaz, Şahin, Haseski ve Erol (2014) 2853 öğrenci ile yapmış olduğu ve öğrencilerin \%16,3'ünün yüksek düzeyde internet bağımlısı olduğu sonucu ile paralellik göstermektedir. Dijital oyun bağımlılık durumları belirlendikten sonra dijital oyun bağımlısı olan çocukların ebeveynleri ve dijital oyun bağımlısı olmayan çocukların ebeveynleri ile görüşmeler yapılmıştır.

Çalışmada ebeveynlerle yapılan görüşmeler sonucu temalar oluşturulmuştur. Her ne kadar bu temalar kategorize edilse de grupların birbirinden çok kesin çizgiler ile ayrıldığının söylenmesi güçtür. Fakat bu gruplama ve genellemeler her iki aile türüne ait bir aile profilinin çıkarılması ve bazı yorumların yapılabilmesi açısından önemlidir. Çocukları dijital oyun bağımlısı olduğu düşünülen ailelerin; çocuklarına yeterli ilgiyi gösteremedikleri, aile içerisindeki iletişimde bazı problemlerin olduğu, çocuklara şiddet uygulamaya varan davranışların olduğu görülmüştür. Ebeveynler çocuklarının aşırı bir şekilde dijital oyunlar 
oynaması hakkında kendilerini çaresiz hissetmiş, bu konuda suçu çocuklarının arkadaş çevresi veya okulda görmüşlerdir. Dijital oyun bağımlısı olmadığı düşünülen çocukların aileleri ise; daha geniş bir aile modeline sahip olmakta, aile içerisinde huzura önem verilmekte, yasaklar yerine kurallar işletilmekte, ailece etkinliklerin yapılmakta olduğu; ayrıca özellikle annenin çocuğuyla yakından ilgilendiği görülmüştür. Her iki aile grubundan ebeveynlerin kendi ailelerini muhafazakâr olarak nitelediği, çocuklarını İslami ahlakla büyütmeye çalıştığı, teknolojinin olumsuz yönlerinden haberdar oldukları da çalışmanın sonuçları arasında yer almıştır.

Çocukların dijital oyun bağımlısı olup olmamasında ailenin kalabalık yapısı, aile içerisindeki kural ve sınırlar, anne veya babanın çocukla ilgilenme durumu, ailece yapılan sosyal etkinlikler, teknoloji ve zararlarına ilişkin farkındalık gibi bazı faktörlerin varlığı belirlenmiştir. Elde edilen sonuçlara göre bazı değişkenlerin çocukların dijital oyun bağımlısı olmasında etkili olduğu, bazı değişkenlerin ise etkili olmadığı görüşüne varılmıştır. Çocukların dijital oyun bağımlılığında rol oynadığı düşünülen faktörler yapılan görüşmelerle belirlenmiştir.

Aile yapısının geniş olması çocuğun daha çok kişi ile iletişime geçmesini, zamanının çoğunu onlarla geçirmesini sağladığından çocuğun dijital oyunlara yönelme ihtiyacinı en aza indirdiği şeklinde yorumlanabilir. Geleneksel aile yapısına sahip olan çocuklar aile içerisinde daha fazla kişiden ilgi görebilmektedir. Buna karşın çekirdek aile yapısına sahip, özellikle de hem annenin hem de babanın çalıştı̆ğ ailelerde yaşayan çocuklar çoğu zaman yalnız kalabilmekte, can sıkıntısı veya birileri ile iletişim kurma ihtiyaçlarından dolayı dijital oyunlara yönelebildiği görülebilmektedir. Bu sonuçlara benzer olarak, Küçük-Biçer ve Üner (2013) ebeveynleri ayrılmış ve kardeşi olmayan çocukların internet bağımlısı olma ihtimallerinin daha yüksek olduğunu ifade etmişlerdir.

Annenin çocuğu ile daha fazla ilgilenmesi, babanın da çocuğuna arkadaş gibi davranması çocuğun kendini daha rahat hissetmesine ve özgürce ifade etmesine olanak sağlayabilir. Fakat anne veya babanın baskıcı olduğu, aile içerisinde kesin sınırların çizildiği, iletişimin sağlıklı olmadığı durumlarda çocukların daha çok yalnızlaşabileceği, içine kapanık olabileceği ve dijital oyunlar gibi başka yollara başvurabilecekleri muhtemeldir. Bu sonuçlar, çocuklarına karşı daha ihmalkâr olan, onlara yeterli ilgiyi gösteremeyen ailelerin çocuklarının daha fazla internet bağımlısı olduğunu gösteren araştırmalar ile örtüşmektedir (Ayas ve Horzum, 2013; Günüç ve Doğan, 2013; Young, 1997). Ayas ve Horzum (2013) yaptıkları çalışmada ihmalkâr tutuma sahip ailelerde büyüyen çocukların otoriter, müsamahakâr ve 
demokratik tutuma sahip ailelerde büyüyen çocuklara oranla daha fazla internet bağımlısı olduğu sonucuna ulaşmışlardır. Aynı çalışmada internet bağımlılığında, ihmalkâr aile internet tutumunun etkisine de vurgu yapılmıştır.

Çocuğun sosyal etkinliklere yönlendirilip teşvik edilmesi, spor faaliyetlerinin desteklenmesi, aile toplantıları, ailece yapılan etkinlikler ebeveyn-çocuk ilişkisini güçlendirdiğinden çocukların dijital oyunlarla olan bağlarını azaltmaktadır. Aile içerisinde destek göremeyen, kendisine ilgi gösterilmeyen, sosyal etkinliklere katılımı kısıtlanan çocukların ise daha fazla dijital oyun bağımlısı olduğu görülmektedir. $\mathrm{Bu}$ yargıları destekleyici olarak Günüç ve Doğan (2013) yaptıkları bir çalışmada, ailedeki sosyal destek eksikliğinin çocuğu bağımlılığa yönlendireceğini ifade etmişlerdir.

$\mathrm{Bu}$ çalışmada ortaya çıkan önemli bir bulgu da annelerin çocukları üzerindeki rollerinin ne kadar önemli olduğuna ilişkindir. Çalışmada ebeveynlerle iletişim kurulurken, okul kayıtlarından yararlanılmıştır. Çocuklarını okullara kayıt yaptıran ebeveynlerle iletişime geçilmiş ve görüşmeler yapılmıştır. Bu noktada, bağımlı olduğu düşünülen çocukların ebeveynlerinden babaların çocuklarını okula kayıt ettirdikleri, bağımlı olmadığı düşünülen çocukların ebeveynlerinden yarısının ise annelerin çocuklarını kayıt ettirdikleri sonucuna ulaşılmıştır. Bu sonuç ile çocukları üzerinde sorumluluğu yüklenen anneler olduğu zaman ve anneler çocukları ile daha çok ilgilendiklerinde bağımlılık riskinin azaldığı yorumu yapılabilir. Bu sonuçlar Günüç ve Doğan'ın (2013) yaptığı çalışmada annelerin bağımlılıktaki öneminin ne derece büyük olduğunu gösterdikleri sonuçlarla da paralellik göstermektedir.

Çocukları dijital oyun bağımlısı olduğu düşünülen ailelerin, aile içerisinde daha çok çatışma yaşadığı, çocuklarına yeteri kadar ilgi göstermedikleri/gösteremedikleri, iletişim kopukluğu yaşadıkları, hatta bazı ailelerin ise çocuklarına şiddet gösterdiği ortaya çıkmıştır. $\mathrm{Bu}$ tür ailelerde yetişen çocukların dijital oyunları bir kaçış aracı olarak görmesi muhtemeldir. Çalışkan ve Özbay (2015) yaptıkları bir çalışmada, çocukların; aile içerisinde çatışma, yetersiz ilgi, olumsuz aile davranışları gibi faktörlerden olumsuz etkilendiği ve kendilerini daha iyi hissedecekleri internet kafe ve bilgisayar oyunlarına yöneldiği ifade edilmiştir.

Çocuklarının dijital oyun bağımlısı olduğunu düşünen birçok ebeveyn bağımlılık ile mücadele konusunda, bu çalışmadaki bulgularda da görüldüğü üzere, kendilerini çaresiz hissetmektedirler. Bu noktada Aile ve Sosyal Politikalar Bakanlığı (2011) tarafından yapılan “Türkiye'de Aile Yapısı Araştırmasıı” adlı çalışmada eşler çocukları ile sorun yaşadıklarında, bir uzman ya da kurumdan destek aldıklarını söyleyenlerin oranının sadece \%7 olarak 
bulunduğu belirtilmiştir. Bu sonuçlara benzer olarak Demirel, Yörük ve Özkan (2012) Avrupa Çevrimiçi Çocuklar Projesi III (EU Kids Online III) raporu verilerine göre; ülkemizdeki ailelerin Avrupa'daki ailelere oranla çocuklarına daha az seviyede yardım edebildiklerini belirtmişlerdir.

Dijital teknolojiler hemen hemen hayatımızın her alanında etkili bir şekilde kullanılmaktadır. Anne ve babaların dijital teknolojiler hakkında bilgi sahibi olması, dijital teknolojinin yanlış kullanılmasının doğurabileceği zararları bilmesi, çocuğunu bu zararlardan koruması veya etkilerini en aza indirmesi açısından önemlidir. Kaldı ki, dijital oyunların masum olduğunu düşünen ya da içerikleri hakkında bilgisi olmayan ebeveynlerin sayısının oldukça fazla olduğu söylenebilir. Kırık (2014) yaptığı çalışmada ebeveynlerin yarısı, çocukları internette zaman geçirirken onları takip etmediklerini ve kendi işleriyle meşgul olduklarını söylediklerini ifade etmiştir. Ayrıca ebeveynlerin büyük bir kısmının internetin olumsuz sonuçlarına karşı çözüm aramadığını, çocukları korumak için yeterli önlemleri almadıklarını belirtmiştir. Livingstone, Leslie, Anke ve Kjartan (2011) yaptıkları araştırmada bu yargıya benzer olarak, anne ve babaların çocuklarının internet kullanımına rehberlik etme ve müdahale etme oranının en düşük olduğu ülkelerden biri \%73'lük oranla Türkiye olduğu sonucunu paylaşmışlardır.

Elde edilen sonuçlardan çocukları dijital oyun bağımlısı olmadığı düşünülen ebeveynlerin dijital teknolojilerin zararlarına ilişkin farkındalıklarının, çocukları dijital oyun bağımlısı olduğu düşünülen ebeveynlerinkinden daha fazla olduğu anlaşılmıştır. Bu sonuçlar anne ve babanın teknolojiyle olan ilişkisinin, çocuğun da teknoloji ile olan ilişkisini etkilediği yönündeki çalışma bulgularına paralellik göstermektedir (Akkoyunlu ve Tuğrul, 2002; Çetinkaya ve Sütçü, 2016). Öte yandan, dijital teknolojilerin zararları konusunda farkındalığı olan ailelerin bu anlamda çocuklarını sınırlandırdıkları ve kontrol altında tuttukları yargısı güçlenmektedir.

Çalışma grubunun hepsi sosyo-ekonomik düzey bakımından iyi şartlara sahip olduğundan, çocuklar dijital oyunları oynayabilecekleri teknolojik cihazlara sahip olma konusunda sorun yaşamamaktadırlar. Fakat çocuğu bağımlı olmadığı düşünülen ailelerin teknolojiye ilişkin farkındalıklarından dolayı bu cihazlara sahip olma noktasında çocuklarına kısıtlama getirdiği, bağımlı olduğu düşünülen çocukların ailelerin ise bu konuda daha özensiz ve umursamaz davrandığı söylenebilir. Böylece daha fazla dijital oyun oynama olanağı bulan çocukların bağımlı olma riskleri de artmaktadır. 
Çalışmanın bir başka sonucu da çocukları dijital oyun bağımlısı olmadığı düşünülen ailelerle yapılan görüşmelerde aile yapıları hakkında daha az sayıda olumsuz temanın çıkmış olmasıdır. Nitekim çocukları dijital oyun bağımlısı olduğu düşünülen ebeveyn grubunda ”’letişim kopukluğu, çocuğa yeterli ilgi gösterememe, çocuğun bazen tek başına kalmasl, aşırı tepki, annenin daha az toleranslı ve daha çok disiplinli olduğu, çocuğa hafif ya da ă̆ır şiddet, ebeveyn-çocuk çatışması, çocuğun aileyi reddetmesi, ebeveyn-çocuk paylaşımının az olması, anne ve baba arasında çatışma, ebeveynlerin iş yoğunluğu, baskıcı baba, kesin kurallar koyma, huzursuzluk” gibi olumsuzluklar, çocukları dijital oyun bağımlısı olmadığı düşünülen ebeveyn grubuna göre daha fazla görülmüştür. Bu durum sağliklı aile yapısının, çocukları dijital oyun bağımlısı olan ebeveyn grubunda bağımlılığının oluşmasını engelleme noktasındaki rolüne işaret etmektedir.

$\mathrm{Bu}$ çalışmada ayrıca çocuklardaki oyun bağımlılığına etkisi olmadığı düşünülen bazı faktörler tespit edilmiştir. Bunlar; ailelerin kendilerini muhafazakâr olarak nitelemesi, aile kavramı ile ilgili genel bir bilince sahip olmaları, ebeveynlerden birisinin zaman zaman aşırı baskıcı olması, ailelerin çocuklarını İslami bir ahlak ile yetiştirmeye çalışmaları gibi faktörlerdir. Bu durum, her iki grupta da benzer sayıda görüldüğü için çocukların dijital oyun bağımlısı olup olmamalarında bir rol oynamadığı şeklinde yorumlanabilir.

Çocukların dijital oyun bağımlısı olup olmamasında birçok faktör etkili olabilmektedir. Bu çalışmada sadece aile yapısı ve aile içi iletişim boyutlarının incelenmesi çalışmanın bir sınırlığg olarak görülebilir. Bu nedenle aile kadar sosyal çevrenin, arkadaş gruplarının, maddi olanaklar gibi değişkenlerin dijital oyun bağımlılığına etkilerinin bütüncül olarak ele alınacağı çalışmaların yapılması dijital oyun bağımlılığını önleme ve tedavi etme noktasında daha sağlıklı sonuçlar verebileceği düşünülmektedir. Ayrıca çalışmada aile yapısı ve aile içi iletişim gibi kavramlar incelenirken bu ailelerin büyüklüğü, aile bilincinin olup olmadığı, aile bireylerinin birbiri ile olan iletişimlerinin şekli, ailece yapılan etkinliklerin varlığı, ebeveynlerin aile içerisindeki rolleri, çocukların aile içerisinde kendilerini ifade etme durumları gibi değişkenler ele alınmıştır. Oysa aile kavramının daha detaylı olarak incelenmesi, aile içi iletişimin daha net olarak ortaya konulması, özellikle anne ve babanın yaşam tarzları, hayat görüşleri, karakterleri gibi değişkenlerin de belirlenip çocukların dijital oyun bağımlılığı ile ilişkisinin incelenmesi ileriki çalışmalar için önerilmektedir. Çalışmanın bir başka sınırlılığı ise sadece sosyo-ekonomik düzey bakımından iyi durumda olan özel kolejde okuyan çocuk ve ebeveynlerine ulaşılmış olmasıdır. Fakat dijital oyunlar günümüzde toplumun her kesimi tarafından oynanabilmektedir. Bu yüzden sosyo-ekonomik düzeyi iyi 
olmayan ailelerin de dijital oyun bağımlılığına etkisinin incelenmesi ve sosyo-ekonomik düzeyi iyi olan grupla karşılaştırılması da ileriki çalışmalarda ele alınabilir.

\section{Makalenin Bilimdeki Konumu (Yeri)}

Psikoloji Bölümü, Bilgisayar ve Öğretim Teknolojileri Eğitimi Bölümü

\section{Makalenin Bilimdeki Özgünlüğü}

Teknoloji bağımlılığı çocukları her geçen gün daha fazla tehdit etmektedir. Bağımlılık yapan etkenlerden önemli bir tanesi de dijital oyunlardır. Dijital oyun bağımlılığında aile yapısının, özellikle annenin rolünün incelenmesi önemlidir. Alanyazında dijital oyun bağımlılığı ile ilgili birçok çalışmaya rastlanmak mümkündür. Bu çalışma ise teknolojiye ulaşma problemi olmayan, sosyo-ekonomik düzeyi iyi olan çocuklarla yapılası açısından ve çocukların dijital oyun bağımlılığında aile yapılarının incelenmesi, özellikle çocukla daha fazla zaman geçiren annenin rolünün incelenmesi bakımından önemlidir. Alanyazın incelendiğinde oyun bağımlılığının nedenleri konusunda çeşitli araştırmaların yapıldı̆̆ görülmektedir. Fakat dijital oyun bağımlılığında ebeveynlerin ne gibi etkilerinin olduğu konusunda sınırlı sayıda çalışma olduğu görülmektedir. Hem aile yaşantılarından kaynaklanan farklılıkların dijital oyun bağımlılığı üzerindeki olası etkilerinin bilinmesi hem de çocukların bağımlı olmadan önce ebeveynlerin çocukları üzerindeki etkilerinin bilinmesi önemlidir. $\mathrm{Bu}$ çalışma, aile yaşantısı ile ebeveynlerin dijital oyunlara yönelik tutum ve davranışlarının bağımlılık düzeylerine etkisinin belirlenmesi durumunda, bağımlılığın tedavisi ve özellikle de önlenmesi konusunda önemli katkılar sunacaktır.

\section{Kaynaklar}

Akkoyunlu, B. ve Tuğrul, B. (2002). Okul öncesi çocukların ev yaşantısındaki teknolojik etkileşimlerinin bilgisayar okuryazarlığı becerileri üzerindeki etkisi. Hacettepe Üniversitesi Ĕ̈itim Fakültesi Dergisi, 2002;23:12-21.

American Psychiatric Association. (2013). Diagnostic and statistical manual of mental disorders. 5th edition. Arlington: VA American Psychiatric Publishing.

Ayas, T. ve Horzum, M. B. (2013). İlköğretim öğrencilerinin İnternet bağımlılı̆̆ı ve aile İnternet tutumu. Türk Psikolojik Danışma ve Rehberlik Dergisi, 4(39), 46-57.

Baki, A. ve Gökçek, T. (2012). Karma yöntem araştırmalarına genel bir bakış. Elektronik Sosyal Bilimler Dergisi, Güz-2012 Cilt:11 Sayı:42 (001-021).

Brown, T.A. (2006). Confirmatory factor analysis for applied research. NY: Guilford Publications. 
Bülbül, H., Tunç, T. ve Aydil, F. (2018). Üniversite Öğrencilerinde Oyun Bağımlılı̆̆ı: Kişisel Özellikler ve Başarı İle İlişkisi. Ömer Halisdemir Üniversitesi İktisadi ve İdari Bilimler Fakültesi Dergisi, 11 (3), 97-111.

Büyüköztürk, Ş. (2014). Sosyal Bilimler İçin Veri Analizi El Kitabı. 19. Bask1. Ankara: Pegem Akademi.

Creswell, J. W. (2014). Nitel Araştırma Yöntemleri Beş Yaklaşıma Göre Nitel Araştırma ve Araştırma Deseni. Çev. Bütün, M. ve Demir, S.B., Ankara: Siyasal Kitapevi.

Çalışkan, Ö. ve Özbay, F. (2015). 12-14 yaş aralığındaki ilköğretim öğrencilerinde teknoloji kullanımı eksenli yabancılaşma ve anne baba tutumları: Düzce ili örneği. Uluslararası Sosyal Araştırmalar Dergisi, Cilt: 8 Sayı: 39.

Çetinkaya, S. ve Sütçü, S.S. (2016). Çocukların gözüyle ebeveynlerinin bilişim teknolojileri kullanımlarına yönelik kısıtlamaları ve nedenleri. Turkish Online Journal of Qualitative Inquiry (TOJQI), Volume 7, Issue 1, January 2016: / Cilt 7, Say1 1, Ocak 2016: 79-116 DOI: $10.17569 /$ tojqi.58102.

Demirel, M., Yörük, M. ve Özkan, O. (2012). Çocuklar için güvenli İnternet: güvenli internet hizmeti ve ebeveyn görüşleri üzerine bir araştırma. Mehmet Akif Ersoy Üniversitesi Sosyal Bilimler Enstitüsü Dergisi, Y11: 4 Sayı: 72012 Güz.

Durmuş, A. ve Kaya, S. (2008). İlköğretim öğrencilerinin bilgisayar kullanım alışkanlıkları ile velilerin bilgisayar kullanım alışkanlıkları arasındaki ilişki. VIII. Uluslararası Ĕ̈itim Teknolojileri Konferansi.121-126.

Erboy, E. ve Vural-Akar, R. (2010). İlköğretim 4. ve 5. sınıf öğrencilerinin bilgisayar oyun bağımlılı̆̆ını etkileyen faktörler. Ege Eğitim Fakültesi Dergisi, 11(1), 39-58.

Gökçearslan, Ş. ve Durakoğlu, A. (2014). Ortaokul öğrencilerinin bilgisayar oyunu bağımlılık düzeylerinin çeşitli değişkenlere göre incelenmesi. Dicle Üniversitesi Ziya Gökalp Eğitim Fakültesi Dergisi, 23(2014) 419-435.

Göldağ, B. (2018). Lise Öğrencilerinin Dijital Oyun Bağımlılık Düzeylerinin Demografik Özelliklerine Göre İncelenmesi. Yüzüncü Yıl Üniversitesi Eğitim Fakültesi Dergisi, 15 (1), 1287-1315.

Günüç, S. ve Kayri, M. (2010) Türkiye'de internet bağımlılık profili ve İnternet bağımlılık ölçeğinin geliştirilmesi: geçerlik güvenirlik çalışması. Hacettepe Üniversitesi Ĕgitim Fakültesi Dergisi, 2010; (39): 220-232. 
Günüç, S. (2009). İnternet bağımlılık ölçeğinin geliştirilmesi ve bazı demografik değişkenler ile Internet bă̆ımlılı̆̆ı arasındaki ilişkinin incelenmesi (Yayımlanmış yüksek lisans tezi, Van Yüzüncü Y1l Üniversitesi, Eğitim Bilimleri Enstitüsü, Van ).

Günüç, S. (2015). Relationships and associations between video game and internet addictions: is tolerance a symptom seen in all conditions. Computer in Human Behavior. 2015; 49: 517-525.

Günüç, S. ve Doğan, A. (2013). The relationships between Turkish adolescents' İnternet addiction, their perceived social support and family activities. Computers in Human Behavior, 29(6), 2197-2207.

Hooper, D., Coughlan, J. ve Mullen, M. (2008). Structural equation modelling: Guidelines for determining model fit. The Electronic Journal of Business Methods, 6(1), 53-60.

Kayri, M. (2007). Two-Step Cluster Analysis in Researches: A Case Study. Eurasian Journal of Educational Research, 28(1): 177-189.

Kayri, M., Tanhan, F. ve Tanrıverdi, S. (2014). Ortaöğretim öğrencilerinde İnternet bağımlılığg ile algılanan sosyal destek arasındaki ilişkinin incelenmesi. Online Journal Of Technology Addiction \& Cyberbullying, 1 (July,2014).

Kayri, M. ve Günüç, S. (2016). Yüksek ve düşük sosyoekonomik koşullara sahip öğrencilerin İnternet bağımlılığı açısından karşılaştırmalı olarak incelenmesi. Addicta: The Turkish Journal on Addiction, 3, 165-183.

Kırık, A.M. (2014). Aile ve çocuk ilişkisinde İnternetin yeri: nitel bir araştırma. Eğitim ve Öğretim Araştırmaları Dergisi, Cilt:3 Sayı:1 Makale No: 32 ISSN: 2146-9199.

Kim, D. H., Jeong, E. J. ve Zhong, H. (2010). Preventive role of parents in adolescent problematic internet game use in Korea. Korean Journal of Sociology, 44(6), 111-133.

Kline, R.B. (2011). Principles and practice of structural equation modeling (3.bs). New York: The Guilford Press.

Küçük, B.B. ve Üner, S. (2013). Etlik kız teknik ve meslek lisesi 9-11. sınıf öğrencilerinde internet kullanım davranışları ve internet bağımlılığı sıklığının araştırılması. Çocuk ve Bilişim Dergisi. Sanaldan Gerçeğe Sorunlar, Çözüm Önerileri ve İyi Uygulama Örnekleri, 435-451.

Lemmens, J. S., Valkenburg, P. M. ve Peter, J. (2009). Development and validation of a game addiction scale for adolescents. Media Psychology, 12(1), 77 - 95.

Livingstone, S., Leslie H., Anke, G. ve Kjartan, O. (2011). Risks and safety on the internet: the perspective of european children report, EU Kids online deliverable d4: core 
findings to the european commission safer İnternet programme online gaming. Cyberpsychology \& Behavior, 6(1), 81-91.

$\mathrm{Ng}$, B.D. ve Wiemer-Hastings, P. (2005). Addiction to the Internet and online gaming. CyberPsychology \& Behavior. 2005; 8(2),:110-113.

Rosen, L.D., Cheever, N.A. ve Carrier, L.M. (2008). The association of parenting style and child age with parental limit setting and adolescent MySpace behavior. Journal of Applied Developmental Psychology, 29, 459-471

Sümer, N. (2000). Yapısal eşitlik modelleri: Temel kavramlar ve örnek uygulamalar. Turkish Psychological Articles, 3(6), 49-74.

T.C. Aile ve Sosyal Politikalar Bakanlığı. (2011). Türkiye'de aile yapısı araştırması 2011. Ankara, Afşaroğlu Matbaası.

Tabachnick, G.G. ve Fidell, L.S. (2007). Experimental designs using ANOVA. Belmont, CA: Duxbury.

Taylan, H., Kara, H. ve Durğun, A. (2017). Ortaokul ve Lise Öğrencilerinin Bilgisayar Oyunu Oynama Alışkanlıkları ve Oyun Tercihleri Üzerine Bir Araştırma. PESA Uluslararası Sosyal Araştırmalar Dergisi, 3 (1), 78-87.

TÜİK (Türkiye İstatistik Kurumu). (2013). 06-15 Yaş grubu çocuklarda bilişim teknolojileri kullanımı ve medya.

Wang, E. S. ve Wang, M. C. (2013). Social support and social interaction ties on internet addiction: Integrating online and offline contexts. Cyberpsychology, Behavior and Social Networking, 16, 843-849.

Yılmaz, E., Şahin, Y. L., Haseski, H. İ. ve Erol, O. (2014). Lise öğrencilerinin İnternet bağımlılık düzeylerinin çeşitli değişkenlere göre incelenmesi: Balıkesir ili örneği. Ĕgitim Bilimleri Araştırmaları Dergisi. Uluslararası e Dergi, Cilt:4, Sayı:1

Young, K. (2009). Understanding online gaming addiction and treatment 1ssues for adolescents. The American Journal of Family Therapy, 37(5), 355 - 372.

Young, K. S. (1997). What makes the İnternet addictive: potential explanations for pathological İnternet use. 105th. Chicago, IL: Annual Conference of the American Psychological Association. 


\section{Summary}

\section{Statement of Problem}

One of the most addictive activities on the Internet is digital games. One of the reasons that individuals who are addicted to the Internet prefer the Internet most is digital games (Günüç, 2009). Internet addiction and digital game addiction are interrelated concepts ( $\mathrm{Ng}$ and Wiemer-Hastings, 2005; Günüç, 2015). Although there are studies on digital games in the literature, there are not many studies comparing the families of game addicted individuals and non-game addicted individuals in detail. Hence, it was aimed to determine whether there is a difference between the families of children who are addicted to digital games and the families of children who are not addicted to digital games. In this context, the following research question was formulated for this study: What are the family profiles of private college students who are addicted to digital games and those who are not addicted to digital games?

\section{Method}

A mixed-method design was used in this study. The data collected to describe the digital game addiction levels of children formed the quantitative dimension of the research, while the interviews with parents whose children are digital game addicts and parents whose children are not digital game addicts were the qualitative aspects of the research.

\section{Findings}

Findings of the study have revealed that families whose children are addicted to digital games show less interest in their children, feel helpless against the negative aspects of technology, and can completely prohibit technology for their children in this regard. Besides, it was found out that the parents had some problems in their communication with their children and that they could perpetrate mild or severe violence to their children. On the other hand, when the family structure of the children who are not addicted to digital games is examined, it is seen that families are large, there is a peaceful atmosphere in the family, and there are specific rules rather than strict bans in the family. Similarly, it was observed that not every technological device that children wanted was bought immediately, and the digital games played by children were limited.

\section{Discussion and Conclusion}

In the study, first of all, the addiction status of children was described quantitatively. Then, Two-Step Cluster Analysis was used to determine the level of children's digital game addiction. In the first group, there is a "non-addicted group," and this group consists of 92 
(40.9\%) individuals. The second group includes the "risk group," and there are 99 (44\%) individuals in this group. The third and the last group are the "addicted group," and there are $34(15.1 \%)$ individuals in the group. It has been observed that families whose children are thought to be digital game addicts do not show enough interest to their children, there are some problems in communication within the family and behaviors leading to violence against children. Some factors such as the crowded structure of the family, rules, and limits in the family, the status of caring for the child, social activities carried out by the family, and the awareness of the technology and harms have been found to be the determinants of whether children are addicted to digital games.

\section{Ek 1. Dijital Oyun Bağımlılığı Ölçeği}

\begin{tabular}{|c|c|c|c|c|c|}
\hline $\begin{array}{l}\text { DİJíTAL OYUN BAĞIMLILIĞI ÖLÇEĞİ } \\
\text { Cep telefonu, tablet ya da bilgisayarda oynanan video oyunları, İnternet oyunları, } \\
\text { bilgisayar oyunları, konsol oyunları kastedilmektedir. }\end{array}$ & $\begin{array}{ll} & \\
& \\
& \\
0\end{array}$ & 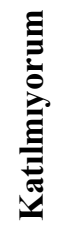 & 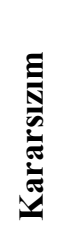 & 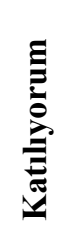 & 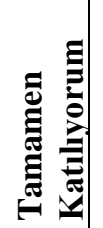 \\
\hline Oyun oynamadığım zaman kendimi gergin/huzursuz hissederim. & 1 & 2 & 3 & 4 & 5 \\
\hline Oyun oynamak isteyip de oynayamadığım zaman sinirli olurum. & 1 & 2 & 3 & 4 & 5 \\
\hline Oyun yavaşlarsa/donarsa/kitlenirse sinirlenirim. & 1 & 2 & 3 & 4 & 5 \\
\hline Oyun oynadığım zamanlarda hiç olmadığım kadar mutlu/huzurlu olurum. & 1 & 2 & 3 & 4 & 5 \\
\hline $\begin{array}{l}\text { Kendimi endişeli ya da sıkıntılı hissettiğim zamanlarda oyun oynamak beni } \\
\text { rahatlatır. }\end{array}$ & 1 & 2 & 3 & 4 & 5 \\
\hline Birileri beni oyunun başından kaldırırsa sinirlenirim. & 1 & 2 & 3 & 4 & 5 \\
\hline Sorunlarımdan kaçmak için oyun oynamaya yönelirim. & 1 & 2 & 3 & 4 & 5 \\
\hline Oyunu planladığım zamanda oynayamazsam sinirlenirim. & 1 & 2 & 3 & 4 & 5 \\
\hline Çevremde birileri varken, yalnız kalıp, oyun oynamayı isterim. & 1 & 2 & 3 & 4 & 5 \\
\hline Oyun oynamadığım zamanlarda oyun oynamak için sabırsızlanırım. & 1 & 2 & 3 & 4 & 5 \\
\hline Gittiğim her yerde oyun oynamak için firsat ararım. & 1 & 2 & 3 & 4 & 5 \\
\hline Oyun oynamamı sınırlamakta ya da kontrol etmekte güçlük çekerim. & 1 & 2 & 3 & 4 & 5 \\
\hline Sabah uyandığımda aklıma ilk gelen şey oyun oynamaktır. & 1 & 2 & 3 & 4 & 5 \\
\hline Oyunda, her defasında bir öncekinden daha uzun süre kalmak isterim. & 1 & 2 & 3 & 4 & 5 \\
\hline Oyunu, planladığımdan daha uzun süre oynarım. & 1 & 2 & 3 & 4 & 5 \\
\hline Oyun oynamadığım zamanlarda bile oyunu düşünürüm. & 1 & 2 & 3 & 4 & 5 \\
\hline Oyun oynarken acıktığımı ya da susadığımı hissetmem/önemsemem. & 1 & 2 & 3 & 4 & 5 \\
\hline Oyunda daha fazla zaman geçirmek için başka planlarımı iptal ederim. & 1 & 2 & 3 & 4 & 5 \\
\hline İstediğim zaman oyunun başından kalkamam. & 1 & 2 & 3 & 4 & 5 \\
\hline Ailem beni çağırsa dahi oyunun başından kalkamam. & 1 & 2 & 3 & 4 & 5 \\
\hline Oyun oynamak için uykumdan ödün veririm. & 1 & 2 & 3 & 4 & 5 \\
\hline Oyun oynamamdan dolayı ailem ile sorunlar yaşarım. & 1 & 2 & 3 & 4 & 5 \\
\hline Arkadaşlarım beni çağırsa dahi oyunun başından kalkamam. & 1 & 2 & 3 & 4 & 5 \\
\hline
\end{tabular}


Oyun oynamamdan dolayı başka etkinliklere (spor, sinema, kitap vb.) ilgim azalır. Oyun oynamamdan dolayı ev/iş/okul sorumluluklarımı yerine getiremem ya da ihmal ederim.

Çevremdekiler, oyunda harcadığım zamandan dolayı şikayet eder.

Oyun oynamamdan dolayı ailem ile daha az zaman geçiririm.

Oyun oynamamdan dolayı arkadaşlarım ile daha az zaman geçiririm.

Oyun oynamamdan dolayı arkadaşlarım ile sorunlar yaşarım.

Oyunda (sanal ortamda) edindiğim arkadaşları gerçek yaşamdaki arkadaşlarıma tercih ederim

Gerçek yaşamdaki arkadaşlarımla dışarıda görüşmek yerine, oyun oynamayı (onlarla birlikte ya da yalnız) tercih ederim.

Arkadaşlarımı sanal ortamdaki oyunlardan edinirim.

Oyun benim en iyi arkadaşımdır.

Oyunsuz bir yaşam bana anlamsı/boş gelir.

Oyun oynamamdan dolayı yüz yüze iletişimde zorluk yaşarım. 